medRxiv preprint doi: https://doi.org/10.1101/2021.01.05.21249216; this version posted January 9,2021 . The copyright holder for this preprint (which was not certified by peer review) is the author/funder, who has granted medRxiv a license to display the preprint in All rights reserved. No reuse allowed without permission.

1 | Prevalence and Factors associated with Mental health impact of COVID-19 Pandemic in Bangladesh: A survey based cross sectional study

\title{
Prevalence and Factors associated with Mental health impact of COVID-19 Pandemic in Bangladesh: A survey based cross sectional study
}

Authors: Tanvir Abir $(\mathrm{PhD})^{1}$; Nazmul Ahsan Kalimullah $(\mathrm{PhD})^{2}$; Uchechukwu, L Osuagwu $(\mathrm{PhD})^{3}{ }^{3}$; Dewan Muhammad Nur -A Yazdani (MSc) ${ }^{4}$; Taha Husain (MA) ${ }^{5}$; Piwuna Christopher Goson (MBBS) ${ }^{6}$; Palash Basak (PhD) ${ }^{7}$; Md Adnan Rahman (MSc) ${ }^{8}$; Abdullah Al Mamun $(\mathrm{PhD})^{9}$; P. Yukthamarani Permarupan $(\mathrm{PhD})^{10}$; Md Yusuf Hossein Khan $(\mathrm{MSc})^{11}$, Kingsley Agho $(\mathrm{PhD})^{12,13}$

\section{Affiliations:}

${ }^{1}$ Associate Professor, College of Business Administration - CBA, International University of Business, Agriculture and Technology_IUBAT University, Dhaka 1230, Bangladesh; tanvir.cba@iubat.edu;

2 Vice-chancellor, Begum Rokeya University, Rangpur-5404, Bangladesh; janipop1995@gmail.com;

${ }^{3}$ Diabetes, Obesity and Metabolism Translational Research Unit, Western Sydney University, Campbelltown, NSW 2560, Australia; l.osuagwu@westernsydney.edu.au;

${ }^{4}$ Assistant Professor, College of Business Administration-CBA, International University of Business, Agriculture and Technology-IUBAT University, Dhaka 1230, Bangladesh; dewanm@iubat.edu;

${ }^{5}$ Lecturer, Department of Gender and Development Studies, Begum Rokeya University, Rangpur 5404, Bangladesh; ahmthusain@gmail.com;

${ }^{6}$ Department of Psychiatry, College of Health Sciences, University of Jos, Nigeria; Email: piwuna01@gmail.com;

${ }^{7}$ School of Environment and Life Sciences (Environmental Science and Management), University of Newcastle, Callaghan 2308, Australia; palash.Basak@gmail.com;

${ }^{8}$ Senior lecturer, College of Business Administration (CBA), International University of Business Agriculture and Technology (IUBAT), Dhaka-1230, Bangladesh; adnan.cba@iubat.edu;

${ }^{9}$ Faculty of Business and Management, UCSI University, Kuala Lumpur 56000, Malaysia; abdullaham@ucsiuniversity.edu.my;

${ }^{10}$ Faculty of Entrepreneurship and Business, Universiti Malaysia Kelantan, Kota Bharu 16100, Malaysia; yuktha@umk.edu.my;

11. College of Tourism and Hospitality Management IUBAT - International University of Business Agriculture and Technology, Dhaka, Bangladesh, PhD Researcher in Tourism University of Algarve, Faro Portugal; Email: ysf.khn86@gmail.com

${ }^{12}$ School of Health Science, Western Sydney University, Campbelltown, NSW 2560, Australia. email: K.Agho@ westernsydney.edu.au

13 African Vision Research Institute (AVRI), University of KwaZulu-Natal, Westville

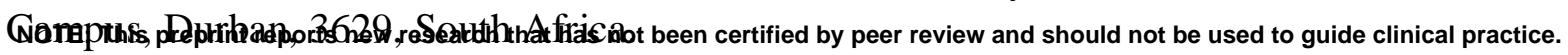


medRxiv preprint doi: https://doi.org/10.1101/2021.01.05.21249216; this version posted January 9,2021 . The copyright holder for this preprint (which was not certified by peer review) is the author/funder, who has granted medRxiv a license to display the preprint in All rights reserved. No reuse allowed without permission.

2 | Prevalence and Factors associated with Mental health impact of COVID-19 Pandemic in Bangladesh: A survey based cross sectional study

*Correspondence: Tanvir Abir (PhD), Associate Professor, College of Business Administration-CBA, International University of Business, Agriculture and TechnologyIUBAT University, Dhaka 1230, Bangladesh; tanvir.cba@iubat.edu

Funding: This research did not receive any funding.

Declaration of Conflict of Interest: The authors declare that they have no known competing financial interests or personal relationships that could have appeared to influence the work reported in this paper.

Author Contribution: Concept and design, Tanvir Abir and Nazmul Kalimullah; Acquisition, analysis, and interpretation of data, Kingsley Ago and Uchechukwu L Osuagwu; Drafting of the manuscript, Christopher Piwuna, Taha Husain and Yazdani; Revision of the manuscript: All authors; Statistical analysis: Kingsley Ago and Tanvir Abir.

Article Type: Original Research.

Keywords: mental health; depression; anxiety; stress; coronavirus; divisions; Bangladesh

Ethics Statement: Ethical permission for this study was obtained from the Institutional Review Board of Dr Wazed Research and Training Institute, Begum Rokeya University, Rangpur (\#BRUR/DWRTI/a.n.004) and the study adhered to the tenets of the Declaration of Helsinki as revised in Fortaleza. All the participants were informed about the specific objective of this study before proceeding to the questionnaire. Consent was obtained from all participants prior to completing the questionnaire through an online preamble. Participants were able to complete the survey only once and could terminate the survey at any time they desired. Anonymity and confidentiality of the data were ensured. 
medRxiv preprint doi: https://doi.org/10.1101/2021.01.05.21249216; this version posted January 9, 2021. The copyright holder for this preprint (which was not certified by peer review) is the author/funder, who has granted medRxiv a license to display the preprint in All rights reserved. No reuse allowed without permission.

3 | Prevalence and Factors associated with Mental health impact of COVID-19 Pandemic in Bangladesh: A survey based cross sectional study

\section{Abstract}

Background: Feelings of isolation, insecurity, and instability triggered by COVID-19 could have a long-term impact on the mental health status of individuals. This study examined the prevalence and factors associated with the mental health symptoms of anxiety, depression, and stress during the COVID-19 pandemic in Bangladesh.

Methods: From $1^{\text {st }}-30^{\text {th }}$ April 2020, we used a validated self-administered questionnaire to conduct a cross-sectional study on 10,609 participants through an online survey platform. We assessed mental health status using the Depression, Anxiety, and Stress Scale (DASS-21). The total depression, anxiety, and stress subscale scores were divided into normal, mild, moderate, severe, and multinomial logistic regression was used to examine associated factors. Results: The prevalence of depressive symptoms was $15 \%, 34 \%$, and $15 \%$ for mild, moderate, and severe depressive symptoms, respectively. The prevalence of anxiety symptoms was $59 \%$ for severe anxiety symptoms, $14 \%$ for moderate anxiety symptoms, and $14 \%$ for mild anxiety symptoms while, the prevalence for stress levels were $16 \%$ for severe stress level, $22 \%$ for moderate stress level and $13 \%$ for mild stress level. Multivariate analyses revealed that the most consistent factors associated with mild, moderate, and severe of the three mental health subscales (depression, anxiety, and stress) were respondents who lived in Dhaka and Rangpur division, females, those who self-quarantine in the previous 7 days before the survey and those respondents who experienced chills, breathing difficulty, dizziness, and sore throat.

Conclusion: Our results showed that about 64\%, 87\%, and 61\% experienced depressive symptoms, anxiety symptoms, and levels of stress, respectively. In Bangladesh, there is a need for better mental health support for females especially those that lived in Dhaka and Rangpur division and experienced chills, breathing difficulty, dizziness, and sore throat during COVID-19 and other future pandemics. 
medRxiv preprint doi: https://doi.org/10.1101/2021.01.05.21249216; this version posted January 9, 2021. The copyright holder for this preprint (which was not certified by peer review) is the author/funder, who has granted medRxiv a license to display the preprint in All rights reserved. No reuse allowed without permission.

4 | Prevalence and Factors associated with Mental health impact of COVID-19 Pandemic in Bangladesh: A survey based cross sectional study

\section{Introduction}

As the global population tries to make sense of the transformations including personal adjustments to lifestyle brought about by the COVID-19 pandemic, residents of low to middle-income countries (LMIC) including Bangladesh face greater challenges due to the fragile health systems $[1,2]$, the dense population of Bangladesh and the fact that the country houses a million stateless Rohingya refugees in sprawling refugee camps that are conducive to the spread of epidemics. Bangladesh also has significant migrant populations living in Italy, a COVID-affected country [1]. Whilst the mortality rates in Bangladesh have remained low, due to the timing of the infection, the early transmission of the virus, and the response to the pandemic by authorities, the low socio-economic status of the country and the existing health inequalities usually lead to worse effects [3].

Science has played a significant role in improving people's understanding of the virus, finding effective ways of containment through timely sequencing of the virus and rapid sharing of the data [4], and most recently the development of different vaccines. Unraveling the genetic sequence of the SARS-COV-2 virus about 4 weeks after the outbreak of the SARS-COV-2 virus [5], which was shorter compared to the Spanish flu which took almost seven decades for the scientist to unravel the genetic sequence of the disease [6], which is crucial to the development of a diagnostic test and potential treatment $[7,8]$.

Globally, the virus has infected over 84 million people, including 1.8 million reported deaths from the infection. In Bangladesh, there have been 515,000 confirmed cases as of $2^{\text {nd }}$ January 2021, with 7576 deaths reported to the WHO [9]. The COVID- 19 pandemic spread faster, and the mortality rate is higher than those attributed to the Middle Eastern respiratory syndrome (MERS) and Severe acute respiratory syndrome (SARS). Thus, there was fear and panic among residents as news about its fatal nature spread very easily through traditional and social media outlets, leaving behind a trail of despair and disruptions in lifestyle. The 
medRxiv preprint doi: https://doi.org/10.1101/2021.01.05.21249216; this version posted January 9, 2021. The copyright holder for this preprint (which was not certified by peer review) is the author/funder, who has granted medRxiv a license to display the preprint in All rights reserved. No reuse allowed without permission.

5 | Prevalence and Factors associated with Mental health impact of COVID-19 Pandemic in Bangladesh: A survey based cross sectional study

high mortality rate, closure of businesses, and strict containment measures by national governments also added to the hidden and unhidden mental health burden of the pandemic $[10,11]$. However, no one has been able to report comprehensively the mental health impact of the pandemic in most Low and Middle Income Countries (LMIC).

Despite the delay in COVID 19 cases in Bangladesh (the first case reported $18^{\text {th }}$ March 2020), the country's global supply chain of International fashion brands and human resource exports suffered a huge set-back with devastating psychosocial consequences emanating from the International and local economic impacts [12]. The rapid spread of the infection and the business climate in Bangladesh, caused fear, worry, and stress as restrictions were put in place by the government. Post-traumatic stress symptoms as well as delayed grief and the sense of loss after multiple deaths and loss of jobs and avenue to socialize have been reported in previous studies [13].

Studies have reported that the COVID-19 pandemic has significant negative impacts on the mental health of college students, with female students reporting higher levels of perceived stress and inability to focus on their academic work [14]. Similarly, couples undergoing Assisted Reproductive Treatment showed the severe psychological impact of the pandemic particularly among women who were more emotionally distressed, anxious, and depressed than their men counterparts. This is because Assisted Reproductive Treatment was stopped in many centers due to rising concern on the impact of COVID-19 on pregnancy [15]. Coupled with these, are the uncertainties about effective treatment, availability of effective vaccine as well as whether life could return to normal.

All these could negatively affect the mental health of the populace and by extension, the productivity of the country that depends largely on international trading, which has so far been decimated by the pandemic. Health care delivery in Bangladesh has major challenges including weak governance and over-centralized framework, the fact that over $58 \%$ of all the 
medRxiv preprint doi: https://doi.org/10.1101/2021.01.05.21249216; this version posted January 9, 2021. The copyright holder for this preprint (which was not certified by peer review) is the author/funder, who has granted medRxiv a license to display the preprint in All rights reserved. No reuse allowed without permission.

6 | Prevalence and Factors associated with Mental health impact of COVID-19 Pandemic in Bangladesh: A survey based cross sectional study

physicians work in the private sector that is poorly regulated, and the lack of funding for the public sector [16]. Layered on top of these, are the lack of resources and disproportionate distribution of mental health services in Bangladesh, leading to poor access to mental health facilities and care [17]. Therefore, this study aims to determine the prevalence and factors associated with mental health symptoms in the population, which could drive the people's economy and wellbeing during and after the pandemic.

\section{Methods}

\section{Study Design}

This cross-sectional online study was conducted from April 1-30, 2020 corresponding to the mandatory lockdown period imposed in different parts of Bangladesh. The Institutional Review Board of Dr. Wazed Research and Training Institute, Begum Rokeya University, Rangpur (\#BRUR/DWRTI/a.n.004), approved the study. This study follows the tenets of the Declaration of Helsinki as revised in Fortaleza. Informed consent was obtained through an online preamble before the respondents began the questionnaire. The participants were assured of the confidentiality of the information provided and their freedom of choice of participation.

A self-administered survey was created using a google form, and since traditional face-toface interviews were not possible due to the lockdown, social media platforms (e.g. Facebook, Google Plus, and Google Form) were used for the distribution of the survey to reach the target respondents living in different parts of Bangladesh. The respondents clicked the link on the platform and responded to the survey voluntarily. This was a convenient sample, and the survey was anonymous, and confidentiality of data was ensured. 
medRxiv preprint doi: https://doi.org/10.1101/2021.01.05.21249216; this version posted January 9,2021 . The copyright holder for this preprint (which was not certified by peer review) is the author/funder, who has granted medRxiv a license to display the preprint in All rights reserved. No reuse allowed without permission.

7 | Prevalence and Factors associated with Mental health impact of COVID-19 Pandemic in Bangladesh: A survey based cross sectional study

\section{Study Population}

The respondents had to be resident in Bangladesh and able to provide online informed consent. To be eligible for participation, participants had to be 18 years and over, and should be able to provide online consent.

\section{Measurements and Covariates}

The covariates, which are shown in Table 1, were classified into four parts: demographic, household factors, compliance with health measures, and health-related factors. The first part gathered demographic information of the participants, including gender, age, living area (division), level of education, marital status, and working status. The second part was the household factors, which asked about living arrangements, the number living together, and the third part included COVID-19 factors, which asked whether the participants have been tested for COVID-19. The fourth part evaluated the compliance to WHO recommended precautionary measures, which included avoiding crowded gatherings, handshaking and use of public transport, wear of facemask when going out, advocate other people about the health risk of the infection. The fifth part evaluated the history of health-related symptoms (if the respondents had experienced any of the following symptoms: fever, pain, headache, chills persistent, dizziness, and breathing difficulties, a couple of weeks before data collection). The information about these five parts is listed in Supplementary Table 1.

The Depression, Anxiety and Stress Scale - 21 Items (DASS-21) is a set of three self-report scales designed to measure the emotional states of depression, anxiety, and stress and were calculated based on a previous study [18]. Responses to each item were rated from 0 to 3 , where "never" (score '0') to 'almost always" (score '3'). Item 3, 5, 10, 13, 16, 17, and 21 (see supplementary table 1) were classified as the depression subscale, and the total depression subscale score was multiplied by 2 to calculate the final score and divided into normal (0-9), mild depression (10-13), moderate depression (14-20), severe depression (21+). The 
medRxiv preprint doi: https://doi.org/10.1101/2021.01.05.21249216; this version posted January 9,2021 . The copyright holder for this preprint (which was not certified by peer review) is the author/funder, who has granted medRxiv a license to display the preprint in All rights reserved. No reuse allowed without permission.

8 | Prevalence and Factors associated with Mental health impact of COVID-19 Pandemic in Bangladesh: A survey based cross sectional study

Cronbach's alpha coefficients measuring internal consistency among the depression subscale score ranged from 0.75 to 0.77 , indicating a satisfactory level of reliability.

The items $2,4,7,9,15,19$, and 20 (see supplementary table 1) formed the anxiety subscale, and the total anxiety subscale score was multiplied by 2 to calculate the final score and divided into normal (0-7), mild anxiety (8-9), moderate anxiety (10-14), severe anxiety (15+) [18]. The Cronbach's alpha coefficient for anxiety subscale scores ranged from 0.65 to 0.77, indicating acceptable internal consistency.

Items $1,6,8,11,12,14$, and 18 (see supplementary table 1) were classified as the stress subscale. The total stress subscale score was multiplied by 2 to calculate the final score and was divided into normal (0-14), mild stress (15-18), moderate stress (19-25), severe stress (26+), and extremely severe stress (35-42) [18]. The Cronbach's alpha coefficient of stress subscale scores ranged from 0.78 to 0.81 , indicating an acceptable level of internal consistency.

\section{Statistical Analysis}

Descriptive statistics using frequency tabulations were used to present the sample characteristics. The prevalence and $95 \%$ confidence intervals of symptoms of depression, anxiety, and levels of stress were calculated for normal, mild, moderate, and severe. The association was further tested by odds ratios (OR) using univariate multinomial logistic regression, and multiple multinomial logistic regression analyses were performed to identify significant factors associated with symptoms of depression, anxiety, and levels of stress.

In the multiple multinomial logistic regression analyses, four-stage modeling was employed. In the first stage, the demographic factors were entered into the first stage model. We conducted a manually executed elimination method to determine factors associated with symptoms of depression, anxiety, and levels of stress at $(\mathrm{p}<0.05)$. The significant factors in the first stage were added to the household factors in the second stage model; this was then 
medRxiv preprint doi: https://doi.org/10.1101/2021.01.05.21249216; this version posted January 9,2021 . The copyright holder for this preprint (which was not certified by peer review) is the author/funder, who has granted medRxiv a license to display the preprint in All rights reserved. No reuse allowed without permission.

9 | Prevalence and Factors associated with Mental health impact of COVID-19 Pandemic in Bangladesh: A survey based cross sectional study

followed by the elimination procedure. We used a similar statistical approach for compliance with public health and Health conditionlfactors in the third and fourth stages, respectively. Associations were presented as unadjusted OR $(95 \% \mathrm{CI})$ for all explanatory variables and then adjusted OR $(95 \% \mathrm{CI})$ for the variables retained in the final step. All statistical analyses were conducted using STATA/MP Version.14.1 (Stata Corp, College Station, TX, USA).

\section{Spatial Analysis}

We conducted spatial distribution for mental health which consisted of depression, anxiety, and stress subscales. A series of maps were prepared using ArcGIS Desktop 10.8 [19]. The average level of depression, anxiety, and stress for the first-level administrative unit of Bangladesh (division) was calculated based on the identification of factors through map comparisons and regression analysis for mild, moderate, and severe levels. In the maps, the adjusted odds ratios (AOR) for each level was categorized into five quantiles and were presented using graduated colour symbols.

\section{Results}

\section{Demographic Characteristics}

From the 10,900 participants, data for 10,660 respondents (aged 18 years and over) deriving out of all 8 divisions in Bangladesh were included in the analysis. 5238 participants (49.1\%) were males and mostly aged between 18-37years (8466, 79.4\%). Of the total number of respondents, $6233(58.5 \%)$ had a university degree or higher, and 5332 (50.3\%) were married. About half of the participants (5260 participants [49.6\%]) lived in Dhaka division, with the family $(8533,80.4 \%)$ or with up to 3 people $(9328,87.9 \%)$ and were working full time or part-time (5974 participants [56.0\%]) during the pandemic. This survey included data from 343 individuals (3.2\%) with confirmed cases of COVID-19 and 832 individuals (7.8\%) with suspected cases of COVID-19. 
medRxiv preprint doi: https://doi.org/10.1101/2021.01.05.21249216; this version posted January 9,2021 . The copyright holder for this preprint (which was not certified by peer review) is the author/funder, who has granted medRxiv a license to display the preprint in All rights reserved. No reuse allowed without permission.

10 | Prevalence and Factors associated with Mental health impact of COVID-19 Pandemic in Bangladesh: A survey based cross sectional study

Of the total number of respondents, the majority enforced protective measures in their homes to protect their families $(9705,91.5 \%)$, had quarantine experience, 8454 (79.7\%) but more than two-third ( 78\% each) did not comply with the public health measures of avoiding public transport, handshaking, large gatherings, wear of facemask when going out, which were put in place to contain the spread of the disease. More than two-thirds of the participants had at least one symptom of COVID-19 a couple of weeks before data collection, especially persistent fever and cough $(9727,91.7 \%)$ and difficulty breathing $(9207,86.8 \%)$. Additional demographic and epidemic-related characteristics are presented in Table 1.

Prevalence and $95 \%$ confidence intervals (CI) of Covid-19 depression, anxiety, and stress

The prevalence of symptoms for the 3 mental health conditions among the total sample is shown in Figures 1 (a-c) for depression, anxiety, and stress, respectively. The prevalence was $65.0 \%$ for depression (6822 participants total, including 1563 participants [14.7\%, 95\%CI, 14.0-15.4\%] with mild depression and 1552 participants [14.6\%, 95\%CI, 13.9-15.3\%] with severe depression), $86.9 \%$ for anxiety (9267 participants total, including 1440 participants [13.5\%, 95\%CI, 12.4-13.7\%] with mild anxiety and 6310 participants [59.2\%, 95\%CI, 58.3$60.1 \%$ ] with severe anxiety), 50.5\% (95\% CI, 28.8\%-29.6\%) for stress (5381 participants total, including 1339 participants [12.6\%, 95\%CI, 12.0-13.2\%] with mild stress and 1684 participants $[15.8 \%, 95 \% \mathrm{CI}, 15.1-16.5 \%]$ with severe stress). Additional details on the prevalence of mental health symptoms in different populations are presented in Figure 1.

\section{Factors Associated with Symptoms of Depression, Anxiety, and Stress}

The results of the unadjusted analysis of demographic and COVID-19 related variables are presented in the supplementary Tables 1-3, for depression, anxiety, and stress, respectively. Table 2 presents the multivariate analysis of factors associated with depression in this cohort. In the multivariable analysis, being married, having lower than a postgraduate degree, living 
medRxiv preprint doi: https://doi.org/10.1101/2021.01.05.21249216; this version posted January 9,2021 . The copyright holder for this preprint (which was not certified by peer review) is the author/funder, who has granted medRxiv a license to display the preprint in All rights reserved. No reuse allowed without permission.

11 | Prevalence and Factors associated with Mental health impact of COVID-19 Pandemic in Bangladesh: A survey based cross sectional study

alone or living in shared accommodation, living in the Sylhet, Dhaka, Chittagong, Rajshahi, and, Rangpur divisions, having experienced any COVID-19 related health symptom couple of weeks before data collection, were found to be associated with symptoms of depression at all levels. Figure 2 presents the adjusted odds ratios for depression symptoms among the respondents by region. The map in Figure 2, indicates that significantly high odds of depression occurred in all 8 regions of Bangladesh with the highest odds of severe depression reported in Rangpur, Sylhet and Chittagong reported (darkest brown colour). Individuals who were tested for COVID-19 also had remarkably higher levels of mild-severe symptoms of depression compared to those that had not been tested. In addition, female participants, those who were divorced or separated, residents of Barisal or Mymensing divisions, and those who traveled by public transport displayed a higher risk of moderate-severe symptoms of depression. Additional details on the factors associated with depression are presented in Table 2. Individuals with confirmed COVID-19 had at least a 50 percent higher risk of moderate-severe depression symptoms compared to those who were not tested for the disease.

Table 3 presents the multivariate analysis of factors associated with anxiety among the participants. Their distribution by region is shown in Figure 3, revealing that the odds for feeling severely anxious increased by more than 3 folds among respondents from four of the eight regions (see Figure 3 for details). From the Table, females, those who were divorced or widowed, those who lived in shared accommodation during the lockdown, individuals who experienced self-quarantine, and those who experienced fever and cough a couple of weeks before data collection, were more likely to experience mild-severe symptoms of anxiety, while older participants experienced a lower risk of depression at all levels. Compared to those from Khulna division, participants who lived in other divisions particularly Chittagong [adjusted OR, 6.26, 95\%CI, 4.40-8.90], Mymensing [adjusted OR, 5.26, 95\%CI, 3.04-9.12] 
medRxiv preprint doi: https://doi.org/10.1101/2021.01.05.21249216; this version posted January 9,2021 . The copyright holder for this preprint (which was not certified by peer review) is the author/funder, who has granted medRxiv a license to display the preprint in All rights reserved. No reuse allowed without permission.

12 | Prevalence and Factors associated with Mental health impact of COVID-19 Pandemic in Bangladesh: A survey based cross sectional study

and Rangpur [adjusted OR, 5.86, 95\%CI, 3.64-9.42] had a higher risk of severe symptoms of depression (see Figure 4) as well as those who lived alone [adjusted OR, 1.70, 95\%CI, 1.352.16] during the lockdown. Those with confirmed or suspected cases of COVID-19 were more about two times more likely to experience severe symptoms of depression compared to those who were not tested. Other symptoms of COVID-19 were also significantly associated with some degree of depression in this study.

The factors associated with stress in the multivariate analysis are shown in Table 4. Females, those living outside of Khulna division, participants with lower than postgraduate education, older people (>27years), participants who were married, those who lived alone, and participants who had experienced self-quarantine and any of the health symptoms in this study (except for fever) were more likely to experience symptoms of stress at all levels. Participants who were divorced/widowed [adjusted OR, 1.54, 95\%CI, 1.06-2.24], those who lived in shared accommodations [adjusted OR, 2.26, 95\%CI, 1.69-3.02] as well as individuals who failed to comply with the precautionary measures advising people to avoid traveling by public transport and/or shake hands [adjusted OR, 1.63, 95\%CI, 1.15-2.30] had a remarkably higher risk of moderate and severe stress symptoms [adjusted OR, 4.02, 95\%CI, 2.74-5.91 and $1.63,95 \% \mathrm{CI}, 1.15-2.30$, respectively for severe stress], while severe stress symptoms were also found among those who failed to wear face masks when going out [adjusted OR, $1.64,95 \% \mathrm{CI}, 1.19-2.25]$.

Table 1 Characteristics of the study population $(n=10609)$

\begin{tabular}{llcc}
\hline Variables & $\mathbf{n}$ & $\begin{array}{l}\text { Percent } \\
(\%)\end{array}$ \\
\hline $\begin{array}{l}\text { Demography } \\
\text { Division of Living }\end{array}$ & & & \\
& Khulna & 1788 & 16.85 \\
& Chittagong & 1198 & 11.29 \\
& Mymensing & 288 & 2.71 \\
\hline
\end{tabular}


medRxiv preprint doi: https://doi.org/10.1101/2021.01.05.21249216; this version posted January 9 , 2021. The copyright holder for this preprint (which was not certified by peer review) is the author/funder, who has granted medRxiv a license to display the preprint in All rights reserved. perpetuity.

perpetuity.
reuse allowed without permission.

13 | Prevalence and Factors associated with Mental health impact of COVID-19 Pandemic in Bangladesh: A survey based cross sectional study

\begin{tabular}{llll}
\hline & Rajshahi & 674 & 6.35 \\
& Barisal & 716 & 6.75 \\
& Rangpur & 464 & 4.37 \\
& Sylhet & 221 & 2.08 \\
& Dhaka & 5260 & 49.58
\end{tabular}

Gender

$\begin{array}{lll}\text { Male } & 5238 & 49.37 \\ \text { Female } & 5371 & 50.63\end{array}$

Level of Education

$\begin{array}{lll}\text { Postgraduate/Post Doctorate } & 2291 & 21.59 \\ \text { Graduate } & 3942 & 37.16 \\ \text { HSC or Equivalent } & 2881 & 27.16 \\ \text { SSC or Equivalent } & 969 & 9.13 \\ \text { Under SSC } & 526 & 4.96\end{array}$

Age Category

$\begin{array}{lll}\text { 18-27 years } & 6043 & 56.96 \\ 28-37 \text { years } & 2423 & 22.84 \\ 38-47 \text { years } & 1157 & 10.91 \\ 48-57 \text { years } & 709 & 6.68 \\ 58+\text { years } & 277 & 2.61\end{array}$

Marital Status

$\begin{array}{lll}\text { Single } & 4833 & 45.56 \\ \text { Married } & 5332 & 50.26 \\ \text { Divorced/Widowed } & 444 & 4.19\end{array}$

\section{Working Status}

Household Factors

$\begin{array}{lll}\text { Working (Full time) } & 4754 & 44.81 \\ \text { Working (Part-time) } & 1220 & 11.50 \\ \text { No working/Student } & 4635 & 43.69\end{array}$

\section{Living Arrangement}

$\begin{array}{lll}\text { Living with Family } & 8533 & 80.43 \\ \text { Living Alone } & 1504 & 14.18 \\ \text { Sharing/Living with } & 572 & 5.39 \\ \text { Flatmates } & & \end{array}$

\section{Household Size}

$\begin{array}{lll}1-2 \text { People } & 1281 & 12.07 \\ 3-4 \text { People } & 9328 & 87.93\end{array}$

Have you been tested for COVID-19? 
medRxiv preprint doi: https://doi.org/10.1101/2021.01.05.21249216; this version posted January 9, 2021. The copyright holder for this preprint (which was not certified by peer review) is the author/funder, who has granted medRxiv a license to display the preprint in All rights reserved. No reuse allowed without permission.

14 | Prevalence and Factors associated with Mental health impact of COVID-19 Pandemic in Bangladesh: A survey based cross sectional study

\begin{tabular}{llll}
\hline No & 9434 & 88.92 \\
& Yes, I Tested Negative & 832 & 7.84 \\
& Yes. I Tested Positive & 343 & 3.23
\end{tabular}

\section{Compliance with Public health measures}

Have You Enforced Protective Measures Inside Your Home to Protect Yourself and Your Family from COVID 19?

$\begin{array}{lll}\text { Yes } & 9705 & 91.48 \\ \text { No } & 904 & 8.52\end{array}$

Are You Currently in Self-Quarantine Since Past Seven Days?

$\begin{array}{lll}\text { No } & 2155 & 20.31 \\ \text { Yes } & 8454 & 79.69\end{array}$

What Sort of Protective Measures Have You Taken?

Avoid Public Transport

$\begin{array}{lll}\text { Yes } & 2230 & 21.02 \\ \text { No } & 8379 & 78.98\end{array}$

Avoid Shaking Hands

$\begin{array}{lll}\text { Yes } & 2313 & 21.80 \\ \text { No } & 8296 & 78.20\end{array}$

Wearing Face Mask

$\begin{array}{lll}\text { Yes } & 2368 & 22.32 \\ \text { No } & 8241 & 77.68\end{array}$

Avoid Large Gatherings

$\begin{array}{lll}\text { Yes } & 2352 & 22.17 \\ \text { No } & 8257 & 77.83\end{array}$

Advocating People About the Health Risk Related to COVID-19

$\begin{array}{lll}\text { Yes } & 1792 & 16.89 \\ \text { No } & 8817 & 83.11\end{array}$

Responses Regarding the Health Condition for the Last Couple of Weeks

Fever For at least A Day

$\begin{array}{lll}\text { No } & 9179 & 86.52 \\ \text { Yes } & 1430 & 13.48\end{array}$

Chills For at least a Day

$\begin{array}{lll}\text { No } & 9225 & 86.95 \\ \text { Yes } & 1384 & 13.05\end{array}$

Headache For at least a day

$\begin{array}{lll}\text { No } & 7851 & 74.00 \\ \text { Yes } & 2758 & 26.00\end{array}$


medRxiv preprint doi: https://doi.org/10.1101/2021.01.05.21249216; this version posted January 9, 2021. The copyright holder for this preprint (which was not certified by peer review) is the author/funder, who has granted medRxiv a license to display the preprint in All rights reserved. No reuse allowed without permission.

15 | Prevalence and Factors associated with Mental health impact of COVID-19 Pandemic in Bangladesh: A survey based cross sectional study

Cough For at least a Day

$\begin{array}{lll}\text { No } & 8228 & 77.56 \\ \text { Yes } & 2381 & 22.44\end{array}$

Breathing Difficulty

$\begin{array}{lll}\text { No } & 9207 & 86.78 \\ \text { Yes } & 1402 & 13.22\end{array}$

Dizziness

$\begin{array}{lll}\text { No } & 8802 & 82.97 \\ \text { Yes } & 1807 & 17.03\end{array}$

Sore Throat

$\begin{array}{lll}\text { No } & 8761 & 82.58 \\ \text { Yes } & 1848 & 17.42\end{array}$

Persistent fever and cough or difficulty in breathing

$\begin{array}{lll}\text { No } & 9727 & 91.69 \\ \text { Yes } & 882 & 8.31\end{array}$

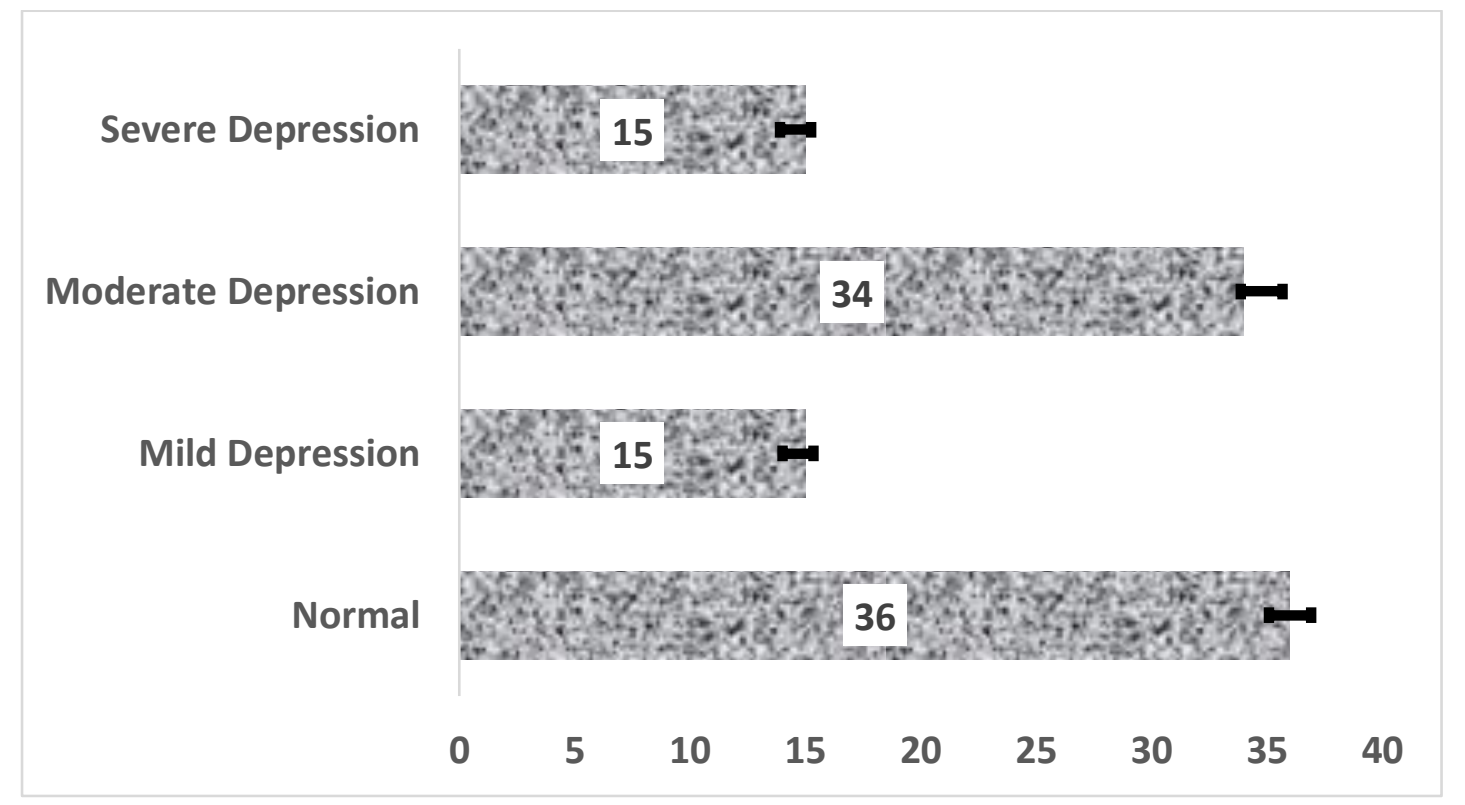

Figure 1 (a): Prevalence and 95\% CI of Depression level during COVID-19 
medRxiv preprint doi: https://doi.org/10.1101/2021.01.05.21249216; this version posted January 9, 2021. The copyright holder for this preprint (which was not certified by peer review) is the author/funder, who has granted medRxiv a license to display the preprint in

All rights reserved. No reuse allowed without permission.

16 | Prevalence and Factors associated with Mental health impact of COVID-19 Pandemic in Bangladesh: A survey based cross sectional study

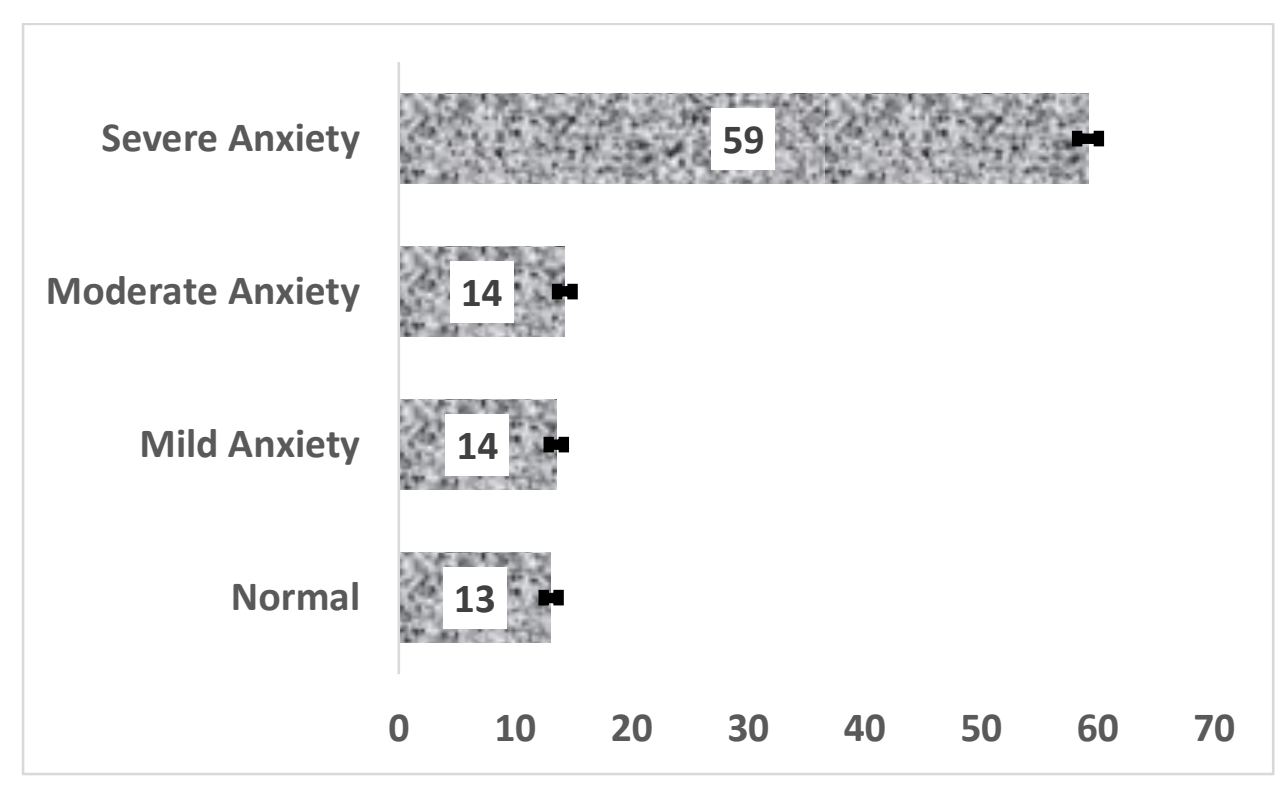

Figure 1 (b): Prevalence and 95\% CI of Anxiety level during COVID-19

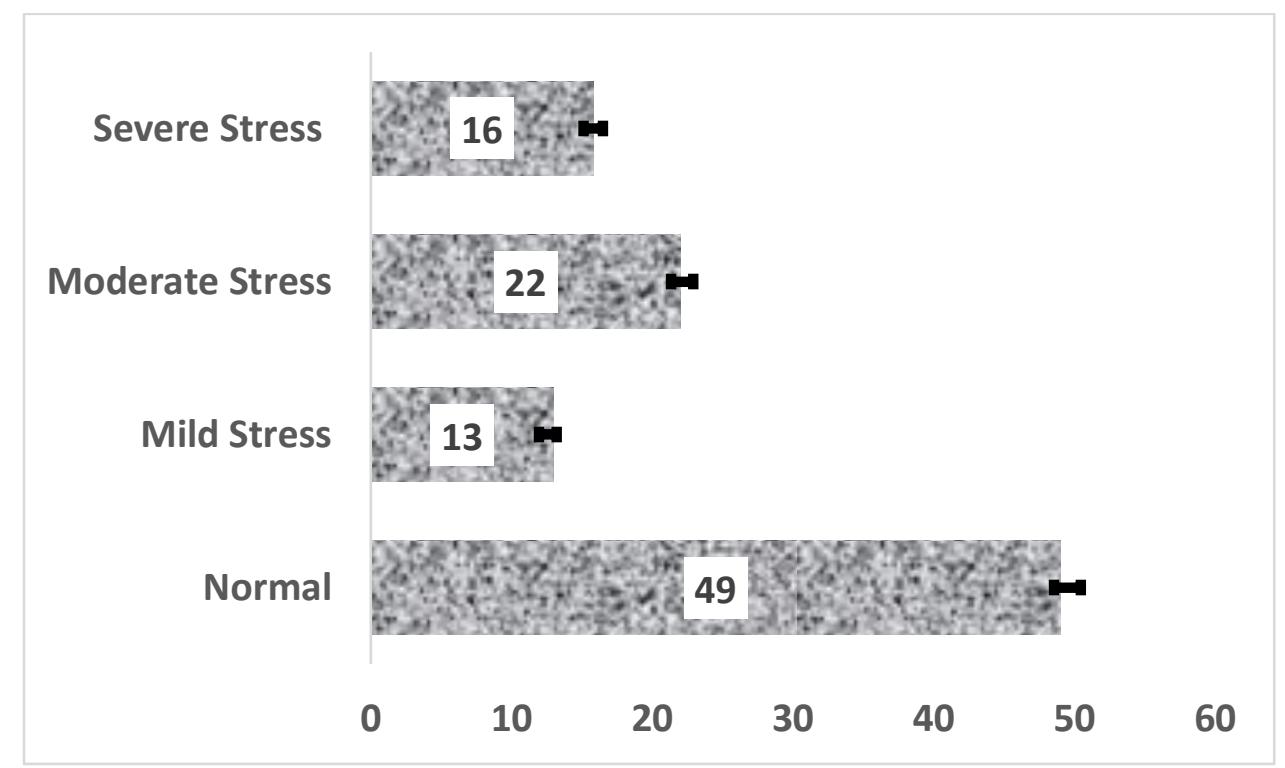

Figure 1 (c): Prevalence and 95\% CI of Stress level during COVID-19 
17 | Prevalence and Factors associated with Mental health impact of COVID-19 Pandemic in Bangladesh: A survey based cross sectional study

Table 2: Factors associated with mild, moderate, and severe depression during COVID-19 in Bangladesh.

\begin{tabular}{|c|c|c|c|c|c|c|}
\hline \multirow[t]{2}{*}{ Variables } & \multicolumn{2}{|l|}{ Mild } & \multicolumn{2}{|l|}{ Moderate } & \multicolumn{2}{|l|}{ Severe } \\
\hline & aOR & Pvalue & aOR & Pvalue & aOR & Pvalue \\
\hline \multicolumn{7}{|l|}{ Demography } \\
\hline \multicolumn{7}{|l|}{ Division of Living } \\
\hline Khulna & 1.00 & & 1.00 & & 1.00 & \\
\hline Chittagong & $2.16(1.65,2.81)$ & $<0.001$ & $4.38(3.47,5.55)$ & $<0.001$ & $6.38(4.77,8.56)$ & $<0.001$ \\
\hline Rajshahi & $1.42(1.01,1.98)$ & 0.042 & $3.56(2.74,4.62)$ & $<0.001$ & $3.77(2.70,5.27)$ & $<0.001$ \\
\hline Barisal & $1.04(0.77,1.41)$ & 0.782 & $1.76(1.36,2.27)$ & $<0.001$ & $2.09(1.50,2.93)$ & $<0.001$ \\
\hline Rangpur & $1.91(1.28,2.86)$ & 0.002 & $5.07(3.65,7.03)$ & $<0.001$ & $5.68(3.82,8.45)$ & $<0.001$ \\
\hline Sylhet & $5.34(2.93,9.75)$ & $<0.001$ & $10.67(6.05,18.81)$ & $<0.001$ & $15.17(8.07,28.53)$ & $<0.001$ \\
\hline Dhaka & $1.85(1.54,2.22)$ & $<0.001$ & $2.48(2.11,2.93)$ & $<0.001$ & $2.88(2.30,3.62)$ & $<0.001$ \\
\hline \multicolumn{7}{|l|}{ Gender } \\
\hline Male & 1.00 & & 1.00 & & 1.00 & \\
\hline Female & $1.14(0.99,1.30)$ & 0.060 & $1.63(1.45,1.83)$ & $<0.001$ & $1.71(1.47,1.98)$ & $<0.001$ \\
\hline \multicolumn{7}{|l|}{ Level of Education } \\
\hline Postgraduate/Post Doctorate & 1.00 & & 1.00 & & 1.00 & \\
\hline Graduate & $1.47(1.24,1.75)$ & $<0.001$ & $1.64(1.41,1.90)$ & $<0.001$ & $1.55(1.28,1.88)$ & $<0.001$ \\
\hline HSC or Equivalent & $1.25(1.03,1.52)$ & 0.026 & $2.00(1.70,2.35)$ & $<0.001$ & $2.19(1.79,2.68)$ & $<0.001$ \\
\hline SSC or Equivalent & $1.53(1.14,2.05)$ & 0.005 & $3.57(2.84,4.48)$ & $<0.001$ & $3.22(2.44,4.24)$ & $<0.001$ \\
\hline Under SSC & $1.61(1.14,2.28)$ & 0.007 & $2.64(1.97,3.53)$ & $<0.001$ & $2.89(2.04,4.10)$ & $<0.001$ \\
\hline \multicolumn{7}{|l|}{ Age in category } \\
\hline $18-27$ years & 1.00 & & 1.00 & & 1.00 & \\
\hline 28-37 years & $1.16(0.94,1.44)$ & 0.166 & $1.21(1.02,1.43)$ & 0.032 & $1.49(1.23,1.82)$ & $<0.001$ \\
\hline $38-47$ years & $0.84(0.63,1.13)$ & 0.246 & $1.10(0.89,1.37)$ & 0.367 & $0.80(0.61,1.04)$ & 0.090 \\
\hline
\end{tabular}


18 | Prevalence and Factors associated with Mental health impact of COVID-19 Pandemic in Bangladesh: A survey based cross sectional study

\begin{tabular}{|c|c|c|c|c|c|c|}
\hline $48-57$ years & $1.90(1.40,2.58)$ & $<0.001$ & $1.18(0.91,1.52)$ & 0.206 & $1.03(0.76,1.39)$ & 0.848 \\
\hline $58+$ years & $0.35(0.19,0.65)$ & 0.001 & $0.96(0.68,1.37)$ & 0.828 & $0.80(0.52,1.25)$ & 0.332 \\
\hline \multicolumn{7}{|l|}{ Marital Status } \\
\hline Single & 1.00 & & 1.00 & & 1.00 & \\
\hline Married & $0.68(0.56,0.84)$ & $<0.001$ & $1.42(1.20,1.68)$ & $<0.001$ & $1.69(1.36,2.10)$ & $<0.001$ \\
\hline Divorced/Widowed & $1.12(0.71,1.78)$ & 0.626 & $1.71(1.15,2.53)$ & 0.008 & $2.43(1.56,3.76)$ & $<0.001$ \\
\hline \multicolumn{7}{|l|}{ Working Status } \\
\hline Working (Full time) & 1.00 & & 1.00 & & 1.00 & \\
\hline Working (Part time) & $1.23(0.97,1.56)$ & 0.089 & $0.74(0.61,0.89)$ & 0.002 & $0.88(0.71,1.10)$ & 0.281 \\
\hline No working/Student & $0.72(0.59,0.89)$ & 0.002 & $0.40(0.33,0.47)$ & $<0.001$ & $0.27(0.22,0.34)$ & $<0.001$ \\
\hline \multicolumn{7}{|l|}{ Household factor } \\
\hline \multicolumn{7}{|l|}{ Living Arrangement } \\
\hline Living with Family & 1.00 & & 1.00 & & 1.00 & \\
\hline Living Alone & $1.27(1.04,1.54)$ & 0.019 & $1.91(1.61,2.28)$ & $<0.001$ & $2.22(1.80,2.74)$ & $<0.001$ \\
\hline Shared accommodation/Living with Flatmates & $1.34(1.02,1.77)$ & 0.039 & $1.77(1.37,2.29)$ & $<0.001$ & $1.68(1.20,2.35)$ & 0.002 \\
\hline \multicolumn{7}{|l|}{ Household Size } \\
\hline 1-2 People & 1.00 & & 1.00 & & 1.00 & \\
\hline 3-4 People & $0.55(0.45,0.78)$ & $<0.001$ & $0.72(0.59,0.87)$ & 0.001 & $0.60(0.48,0.75)$ & $<0.001$ \\
\hline \multicolumn{7}{|l|}{ Have you been tested for COVID-19? } \\
\hline No & 1.00 & & 1.00 & & 1.00 & \\
\hline Yes, I Tested Negative & $1.85(1.38,2.49)$ & $<0.001$ & $2.52(1.94,3.26)$ & $<0.001$ & $2.24(1.67,3.02)$ & $<0.001$ \\
\hline Yes. I Tested Positive & $1.48(0.87,2.54)$ & 0.152 & $2.08(1.31,3.28)$ & 0.002 & $1.92(1.17,3.16)$ & 0.010 \\
\hline \multicolumn{7}{|l|}{ Compliance with Public health measures } \\
\hline \multicolumn{7}{|c|}{ Are You Currently in Self-Quarantine Since Past Seven Days? } \\
\hline No & 1.00 & & 1.00 & & 1.00 & \\
\hline Yes & $0.77(0.66,0.91)$ & 0.002 & $1.41(1.21,1.64)$ & $<0.001$ & $1.89(1.53,2.33)$ & $<0.001$ \\
\hline
\end{tabular}


19 | Prevalence and Factors associated with Mental health impact of COVID-19 Pandemic in Bangladesh: A survey based cross sectional study

\begin{tabular}{|c|c|c|c|c|c|c|}
\hline \multicolumn{7}{|c|}{ Avoid Public Transport } \\
\hline Yes & 1.00 & & 1.00 & & 1.00 & \\
\hline No & $0.91(0.62,1.33)$ & 0.626 & $2.57(1.86,3.56)$ & $<0.001$ & $2.52(1.70,3.73)$ & $<0.001$ \\
\hline \multicolumn{7}{|c|}{ Avoid Shaking Hands } \\
\hline Yes & 1.00 & & 1.00 & & 1.00 & \\
\hline No & $0.69(0.48,1.00)$ & 0.051 & $1.08(0.78,1.48)$ & 0.651 & $1.76(1.20,2.56)$ & 0.003 \\
\hline \multicolumn{7}{|c|}{ Wearing Face Mask when going out } \\
\hline Yes & 1.00 & & 1.00 & & 1.00 & \\
\hline No & $0.92(0.66,1.28)$ & 0.634 & $1.28(0.97,1.71)$ & 0.081 & $1.39(0.99,1.96)$ & 0.057 \\
\hline \multicolumn{7}{|c|}{ Avoid Large Gatherings } \\
\hline Yes & 1.00 & & 1.00 & & 1.00 & \\
\hline No & $1.53(1.10,2.12)$ & 0.011 & $0.62(0.46,0.82)$ & 0.001 & $0.67(0.48,0.95)$ & 0.023 \\
\hline \multicolumn{7}{|c|}{ Advocating People About the Health Risk Related to COVID-19 } \\
\hline Yes & 1.00 & & 1.00 & & 1.00 & \\
\hline No & $0.76(0.61,0.95)$ & 0.017 & $0.50(0.41,0.62)$ & $<0.001$ & $0.56(0.43,0.73)$ & $<0.001$ \\
\hline \multicolumn{7}{|c|}{ Health Condition experienced in the Last Week } \\
\hline \multicolumn{7}{|c|}{ Fever } \\
\hline No & 1.00 & & 1.00 & & 1.00 & \\
\hline Yes & $1.25(0.99,1.57)$ & 0.051 & $0.90(0.74,1.10)$ & 0.290 & $1.37(1.09,1.72)$ & 0.006 \\
\hline \multicolumn{7}{|c|}{ Chills } \\
\hline No & 1.00 & & 1.00 & & 1.00 & \\
\hline Yes & $1.32(1.01,1.72)$ & 0.041 & $2.05(1.65,2.56)$ & $<0.001$ & $2.19(1.72,2.78)$ & $<0.001$ \\
\hline \multicolumn{7}{|c|}{ Headache } \\
\hline No & 1.00 & & 1.00 & & 1.00 & \\
\hline Yes & $1.15(0.98,1.36)$ & 0.089 & $1.43(1.25,1.64)$ & $<0.001$ & $1.13(0.96,1.35)$ & 0.144 \\
\hline Coug̨ & & & & & & \\
\hline
\end{tabular}


20 Prevalence and Factors associated with Mental health impact of COVID-19 Pandemic in Bangladesh: A survey based cross sectional study

\begin{tabular}{|c|c|c|c|c|c|c|}
\hline No & 1.00 & & 1.00 & & 1.00 & \\
\hline Yes & $2.55(2.14,3.03)$ & $<0.001$ & $2.45(2.10,2.86)$ & $<0.001$ & $1.68(1.39,2.02)$ & $<0.001$ \\
\hline \multicolumn{7}{|c|}{ Breathing Difficulty } \\
\hline No & 1.00 & & 1.00 & & 1.00 & \\
\hline Yes & $3.29(2.48,4.35)$ & $<0.001$ & $3.15(2.47,4.03)$ & $<0.001$ & $4.43(3.41,5.76)$ & $<0.001$ \\
\hline \multicolumn{7}{|c|}{ Dizziness } \\
\hline No & 1.00 & & 1.00 & & 1.00 & \\
\hline Yes & $1.92(1.53,2.40)$ & $<0.001$ & $2.42(1.99,2.93)$ & $<0.001$ & $1.86(1.49,2.32)$ & 0.001 \\
\hline \multicolumn{7}{|c|}{ Sore Throat } \\
\hline No & 1.00 & & 1.00 & & 1.00 & \\
\hline Yes & $1.84(1.48,2.27)$ & $<0.001$ & $2.26(1.89,2.70)$ & $<0.001$ & $2.15(1.75,2.65)$ & $<0.001$ \\
\hline
\end{tabular}

Adjusted odd ratios (aOR); 95\% confidence intervals (CI)

Table 3. Factors associated with mild, moderate, and severe anxiety during COVID-19 in Bangladesh

\begin{tabular}{|c|c|c|c|c|c|c|}
\hline \multirow[t]{2}{*}{ Variables } & \multicolumn{2}{|l|}{ Mild } & \multicolumn{2}{|l|}{ Moderate } & \multicolumn{2}{|l|}{ Severe } \\
\hline & aOR & P-value & aOR & P-value & aOR & P-value \\
\hline \multicolumn{7}{|l|}{ Demography } \\
\hline \multicolumn{7}{|c|}{ Division of Living } \\
\hline Khulna & 1.00 & & 1.00 & & 1.00 & \\
\hline Chittagong & $1.38(0.91,2.09)$ & 0.124 & $3.28(2.23,4.83)$ & $<0.001$ & $6.26(4.40,8.90)$ & $<0.001$ \\
\hline Mymensing & $1.57(0.84,2.92)$ & 0.159 & $2.30(1.24,4.26)$ & 0.008 & $5.26(3.04,9.12)$ & $<0.001$ \\
\hline Rajshahi & $0.65(0.44,0.95)$ & 0.026 & $1.11(0.77,1.60)$ & 0.582 & $2.26(1.68,3.04)$ & $<0.001$ \\
\hline Barisal & $1.25(0.92,1.69)$ & 0.149 & $1.07(0.76,1.50)$ & 0.697 & $1.60(1.21,2.11)$ & 0.001 \\
\hline Rangpur & $1.19(0.67,2.11)$ & 0.561 & $2.17(1.26,3.75)$ & 0.005 & $5.86(3.64,9.42)$ & $<0.001$ \\
\hline Sylhet & $3.32(0.38,28.84)$ & 0.277 & $20.25(2.71,151.42)$ & $<0.001$ & $38.54(5.30,280.02)$ & $<0.001$ \\
\hline
\end{tabular}


21 | Prevalence and Factors associated with Mental health impact of COVID-19 Pandemic in Bangladesh: A survey based cross sectional study

\begin{tabular}{|c|c|c|c|c|c|c|}
\hline Dhaka & $1.13(0.93,1.38)$ & 0.233 & $1.70(1.38,2.09)$ & $<0.001$ & $2.91(2.44,3.47)$ & $<0.001$ \\
\hline \multicolumn{7}{|l|}{ Gender } \\
\hline Male & 1.00 & & 1.00 & & 1.00 & \\
\hline Female & $1.20(1.01,1.43)$ & 0.039 & $1.53(1.29,1.82)$ & $<0.001$ & $1.91(1.65,2.21)$ & $<0.001$ \\
\hline \multicolumn{7}{|l|}{ Level of Education } \\
\hline Postgraduate/Post Doctorate & 1.00 & & 1.00 & & 1.00 & \\
\hline Graduate & $1.10(0.89,1.36)$ & 0.363 & $1.19(0.97,1.47)$ & $<0.001$ & $1.51(1.26,1.81)$ & $<0.001$ \\
\hline HSC or Equivalent & $0.75(0.59,0.95)$ & 0.016 & $1.06(0.84,1.34)$ & 0.608 & $1.78(1.46,2.16)$ & $<0.001$ \\
\hline SSC or Equivalent & $0.96(0.69,1.34)$ & 0.811 & $0.88(0.62,1.25)$ & 0.465 & $2.34(1.78,3.07)$ & $<0.001$ \\
\hline Under SSC & $2.13(1.38,3.28)$ & 0.001 & $1.45(0.90,2.33)$ & 0.124 & $3.37(2.30,4.94)$ & $<0.001$ \\
\hline \multicolumn{7}{|l|}{ Age in category } \\
\hline $18-27$ years & 1.00 & & 1.00 & & 1.00 & \\
\hline 28-37 years & $0.46(0.35,0.60)$ & $<0.001$ & $0.60(0.46,0.78)$ & $<0.001$ & $0.45(0.36,0.56)$ & $<0.001$ \\
\hline $38-47$ years & $0.39(0.28,0.54)$ & $<0.001$ & $0.30(0.21,0.42)$ & $<0.001$ & $0.27(0.21,0.36)$ & $<0.001$ \\
\hline $48-57$ years & $0.19(0.12,0.28)$ & $<0.001$ & $0.30(0.20,0.44)$ & $<0.001$ & $0.31(0.23,0.42)$ & $<0.001$ \\
\hline $58+$ years & $0.10(0.056,0.18)$ & $<0.001$ & $0.17(0.10 .0 .29)$ & $<0.001$ & $0.18(0.12,0.26)$ & $<0.001$ \\
\hline \multicolumn{7}{|l|}{ Marital Status } \\
\hline Single & 1.00 & & 1.00 & & 1.00 & \\
\hline Married & $0.76(0.58,0.98)$ & 0.037 & $0.80(0.62,1.03)$ & 0.088 & $1.09(0.88,1.35)$ & 0.433 \\
\hline Divorced/Widowed & $4.98(2.22,11.13)$ & $<0.001$ & $6.38(2.94,13.89)$ & $<0.001$ & $6.00(2.88,12.50)$ & $<0.001$ \\
\hline \multicolumn{7}{|l|}{ Working Status } \\
\hline Working (Full time) & 1.00 & & 1.00 & & 1.00 & \\
\hline Working (Part time) & $0.90(0.66,1.23)$ & 0.505 & $0.90(0.67,1.23)$ & 0.520 & $0.79(0.61,1.01)$ & 0.058 \\
\hline No working/Student & $0.78(0.61,1.01)$ & 0.060 & $0.96(0.74,1.24)$ & 0.761 & $0.51(0.41,0.63)$ & $<0.001$ \\
\hline \multicolumn{7}{|l|}{ Household factor } \\
\hline Living Arrangement & & & & & & \\
\hline
\end{tabular}


22 | Prevalence and Factors associated with Mental health impact of COVID-19 Pandemic in Bangladesh: A survey based cross sectional study

\begin{tabular}{|c|c|c|c|c|c|c|}
\hline Living with Family & 1.00 & & 1.00 & & 1.00 & \\
\hline Living Alone & $0.83(0.62,1.12)$ & 0.227 & $1.13(0.86,1.45)$ & 0.366 & $1.70(1.35,2.16)$ & $<0.001$ \\
\hline Shared accommodation/Living with Flatmates & $1.87(1.19,2.92)$ & 0.006 & $2.10(1.34,3.29)$ & 0.001 & $2.42(1.60,3.64)$ & $<0.001$ \\
\hline \multicolumn{7}{|l|}{ Household Size } \\
\hline 1-2 People & 1.00 & & 1.00 & & 1.00 & \\
\hline 3-4 People & $0.61(0.42,0.88)$ & 0.008 & $0.63(0.45,0.90)$ & 0.011 & $0.37(0.27,0.50)$ & $<0.001$ \\
\hline \multicolumn{7}{|l|}{ Have you been tested for COVID-19? } \\
\hline No & 1.00 & & 1.00 & & 1.00 & \\
\hline Yes, I Tested Negative & $1.02(0.65,1.61)$ & 0.932 & $1.38(0.92,2.07)$ & 0.120 & $1.85(1.31,2.63)$ & 0.001 \\
\hline Yes. I Tested Positive & $1.45(0.56,3.74)$ & 0.439 & $2.44(1.05,5.68)$ & 0.038 & $2.31(1.05,5.09)$ & 0.038 \\
\hline \multicolumn{7}{|l|}{ Compliance with Public health measures } \\
\hline \multicolumn{7}{|c|}{ Are You Currently in Self-Quarantine Since Past Seven Days? } \\
\hline No & 1.00 & & 1.00 & & 1.00 & \\
\hline Yes & $2.27(1.81,2.86)$ & $<0.001$ & $1.53(1.23,1.89)$ & $<0.001$ & $1.44(1.20,1.73)$ & $<0.001$ \\
\hline \multicolumn{7}{|l|}{ Avoid Public Transport } \\
\hline Yes & 1.00 & & 1.00 & & 1.00 & \\
\hline No & $0.40(0.21,0.74)$ & 0.004 & $0.74(0.42,1.32)$ & 0.306 & $1.49(0.88,2.52)$ & 0.135 \\
\hline \multicolumn{7}{|l|}{ Avoid Shaking Hands } \\
\hline Yes & 1.00 & & 1.00 & & 1.00 & \\
\hline No & $0.52(0.28,0.94)$ & 0.030 & $0.48(0.28,0.85)$ & 0.011 & $0.81(0.49,1.34)$ & 0.411 \\
\hline \multicolumn{7}{|l|}{ Wearing Face Mask when going out } \\
\hline Yes & 1.00 & & 1.00 & & 1.00 & \\
\hline No & $2.34(1.40,3.94)$ & 0.001 & $1.15(0.71,1.87)$ & 0.574 & $1.82(1.17,2.81)$ & 0.007 \\
\hline \multicolumn{7}{|l|}{ Avoid Large Gatherings } \\
\hline Yes & 1.00 & & 1.00 & & 1.00 & \\
\hline No & $1.20(0.70,2.05)$ & 0.500 & $0.94(0.57,1.56)$ & 0.819 & $0.48(0.30,0.76)$ & 0.002 \\
\hline
\end{tabular}


23 | Prevalence and Factors associated with Mental health impact of COVID-19 Pandemic in Bangladesh: A survey based cross sectional study

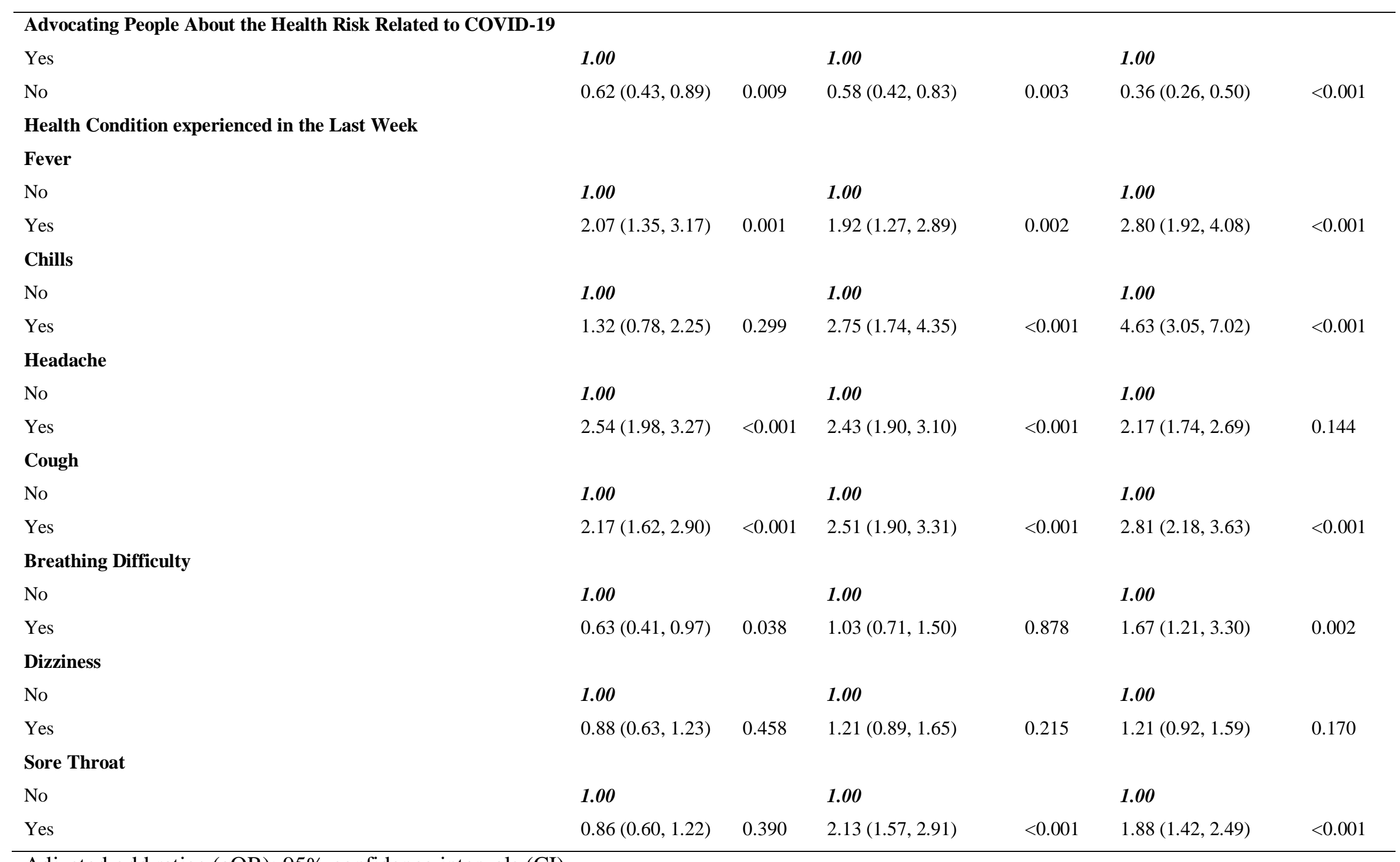

Adjusted odd ratios (aOR); 95\% confidence intervals (CI) 
24 | Prevalence and Factors associated with Mental health impact of COVID-19 Pandemic in Bangladesh: A survey based cross sectional study

Table 4: Factors associated with mild, moderate, and severe Stress during COVID-19 in Bangladesh

\begin{tabular}{|c|c|c|c|c|c|c|}
\hline \multirow[t]{2}{*}{ Variables } & \multicolumn{2}{|l|}{ Mild } & \multicolumn{2}{|l|}{ Moderate } & \multicolumn{2}{|l|}{ Severe } \\
\hline & aOR & Pvalue & aOR & Pvalue & aOR & Pvalue \\
\hline \multicolumn{7}{|l|}{ Demography } \\
\hline \multicolumn{7}{|l|}{ Division of Living } \\
\hline Khulna & 1.00 & & 1.00 & & 1.00 & \\
\hline Chittagong & $2.10(1.61,2.74)$ & $<0.001$ & $3.70(2.92,4.68)$ & $<0.001$ & $2.87(2.17,3.78)$ & $<0.001$ \\
\hline Mymensing & $2.18(1.44,3.29)$ & $<0.001$ & $2.10(1.44,3.08)$ & $<0.001$ & $1.85(1.18,2.89)$ & 0.007 \\
\hline Rajshahi & $3.16(2.36,4.23)$ & $<0.001$ & $2.72(2.05,3.60)$ & $<0.001$ & $2.98(2.18,4.06)$ & $<0.001$ \\
\hline Barisal & $1.25(0.91,1.71)$ & 0.168 & $1.82(1.38,2.39)$ & $<0.001$ & $1.36(0.97,1.89)$ & 0.074 \\
\hline Rangpur & $2.51(1.76,3.58)$ & $<0.001$ & $3.73(2.723,5.11$ & $<0.001$ & $3.21(2.23,4.61)$ & $<0.001$ \\
\hline Sylhet & $2.86(1.81,4.52)$ & $<0.001$ & $2.71(1.72,4.37)$ & $<0.001$ & $3.77(2.32,6.13)$ & $<0.001$ \\
\hline Dhaka & $1.82(1.49,2.23)$ & $<0.001$ & $2.42(2.00,2.91)$ & $<0.001$ & $3.07(2.48,3.80)$ & $<0.001$ \\
\hline \multicolumn{7}{|l|}{ Gender } \\
\hline Male & 1.00 & & 1.00 & & 1.00 & \\
\hline Female & $1.62(1.42,1.87)$ & $<0.001$ & $1.54(1.37,1.74)$ & $<0.001$ & $1.82(1.58,2.09)$ & $<0.001$ \\
\hline \multicolumn{7}{|l|}{ Level of Education } \\
\hline Post Graduate/Post Doctorate & 1.00 & & 1.00 & & 1.00 & \\
\hline Graduate & $1.85(1.54,2.22)$ & $<0.001$ & $2.11(1.80,2.47)$ & $<0.001$ & $1.89(1.58,2.27)$ & $<0.001$ \\
\hline HSC or Equivalent & $1.69(1.38,2.06)$ & $<0.001$ & $1.92(1.62,2.28)$ & $<0.001$ & $1.98(1.64,2.39)$ & $<0.001$ \\
\hline SSC or Equivalent & $2.61(2.02,3.37)$ & $<0.001$ & $2.56(2.03,3.22)$ & $<0.001$ & $3.09(2.41,3.94)$ & $<0.001$ \\
\hline Under SSC & $1.72(1.24,2.40)$ & 0.001 & $1.61(1.20,2.17)$ & 0.002 & $2.43(1.79,3.30)$ & $<0.001$ \\
\hline \multicolumn{7}{|l|}{ Age in category } \\
\hline $18-27$ years & 1.00 & & 1.00 & & 1.00 & \\
\hline 28-37 years & $1.72(1.42,2.09)$ & $<0.001$ & $1.49(1.27,1.76)$ & $<0.001$ & $1.61(1.35,1.92)$ & $<0.001$ \\
\hline 38-47 years & $1.96(1.54,2.50)$ & $<0.001$ & $1.49(1.21,1.84)$ & $<0.001$ & $1.42(1.13,1.80)$ & 0.003 \\
\hline
\end{tabular}


25 | Prevalence and Factors associated with Mental health impact of COVID-19 Pandemic in Bangladesh: A survey based cross sectional study

\begin{tabular}{|c|c|c|c|c|c|c|}
\hline $48-57$ years & $1.16(0.85,1.60)$ & 0.345 & $1.15(0.89,1.49)$ & 0.275 & $1 . .95(1.51,2.51)$ & $\overline{<0.001}$ \\
\hline $58+$ years & $5.31(3.63,7.76)$ & $<0.001$ & $2.25(1.53,3.33)$ & $<0.001$ & $2.83(1.87,4.28)$ & $<0.001$ \\
\hline \multicolumn{7}{|l|}{ Marital Status } \\
\hline Single & 1.00 & & 1.00 & & 1.00 & \\
\hline Married & $1.72(1.41,2.11)$ & $<0.001$ & $1.43(1.20,1.71)$ & $<0.001$ & $2.05(1.67,2.51)$ & $<0.001$ \\
\hline Divorced/Widowed & $1.97(1.38,2.82)$ & $<0.001$ & $1.31(0.94,1.83)$ & 0.106 & $1.54(1.06,2.24)$ & 0.024 \\
\hline \multicolumn{7}{|l|}{ Working Status } \\
\hline Working (Full time) & 1.00 & & 1.00 & & 1.00 & \\
\hline Working (Part time) & $1.11(0.90,1.38)$ & 0.329 & $0.91(0.76,1.10)$ & 0.324 & $0.68(0.56,0.84)$ & $<0.001$ \\
\hline No working/Student & $0.96(0.79,1.17)$ & 0.714 & $0.36(0.31,0.43)$ & $<0.001$ & $0.27(0.22,0.34)$ & $<0.001$ \\
\hline \multicolumn{7}{|l|}{ Household factor } \\
\hline \multicolumn{7}{|l|}{ Living Arrangement } \\
\hline Living with Family & 1.00 & & 1.00 & & 1.00 & \\
\hline Living Alone & $1.60(1.33,1.93)$ & $<0.001$ & $1.67(1.41,1.98)$ & $<0.001$ & $1.71(1.40,2.08)$ & $<0.001$ \\
\hline Shared accommodation/Living with Flatmates & $1.02(0.75,1.40)$ & 0.883 & $1.59(1.23,2.06)$ & $<0.001$ & $2.26(1.69,3.02)$ & $<0.001$ \\
\hline \multicolumn{7}{|l|}{ Household Size } \\
\hline 1-2 People & 1.00 & & 1.00 & & 1.00 & \\
\hline 3-4 People & $0.76(0.62,0.93)$ & 0.007 & $0.74(0.61,0.88)$ & 0.001 & $0.58(0.47,0.70)$ & $<0.001$ \\
\hline \multicolumn{7}{|l|}{ Have you been tested for COVID-19? } \\
\hline No & 1.00 & & 1.00 & & 1.00 & \\
\hline Yes, I Tested Negative & $1.57(1.23,2.01)$ & $<0.001$ & $1.77(1.42,2.21)$ & $<0.001$ & $1.22(0.94,1.57)$ & 0.136 \\
\hline Yes. I Tested Positive & $1.38(0.95,2.01)$ & 0.095 & $1.42(1.01,1.99)$ & 0.046 & $1.10(0.75,1.60)$ & 0.636 \\
\hline \multicolumn{7}{|l|}{ Compliance with Public health measures } \\
\hline \multicolumn{7}{|c|}{ Have You Enforced Protective Measures Inside Your Home to Protect Yourself and Your Family from COVID 19? } \\
\hline Yes & 1.00 & & 1.00 & & 1.00 & \\
\hline
\end{tabular}


26 | Prevalence and Factors associated with Mental health impact of COVID-19 Pandemic in Bangladesh: A survey based cross sectional study

\begin{tabular}{|c|c|c|c|c|c|c|}
\hline No & $1.08(0.85,1.38)$ & 0.540 & $1.18(0.94,1.47)$ & 0.148 & $1.28(1.00,1.65)$ & 0.049 \\
\hline \multicolumn{7}{|c|}{ Are You Currently in Self-Quarantine Since Past Seven Days? } \\
\hline No & 1.00 & & 1.00 & & 1.00 & \\
\hline Yes & $1.28(1.07,1.53)$ & 0.007 & $2.09(1.75,2.49)$ & $<0.001$ & $1.92(1.55,2.38)$ & $<0.001$ \\
\hline \multicolumn{7}{|c|}{ Avoid Public Transport } \\
\hline Yes & 1.00 & & 1.00 & & 1.00 & \\
\hline No & $1.08(0.80,1.47)$ & 0.601 & $1.60(1.20,2.13)$ & 0.001 & $4.02(2.74,5.91)$ & $<0.001$ \\
\hline \multicolumn{7}{|c|}{ Avoid Shaking Hands } \\
\hline Yes & 1.00 & & 1.00 & & 1.00 & \\
\hline No & $0.94(0.70,1.27)$ & 0.700 & $0.68(0.52,0.90)$ & 0.007 & $1.63(1.15,2.30)$ & 0.006 \\
\hline \multicolumn{7}{|c|}{ Wearing Face Mask when going out } \\
\hline Yes & 1.00 & & 1.00 & & 1.00 & \\
\hline No & $1.25(0.95,1.64)$ & 0.107 & $1.15(0.89,1.48)$ & 0.291 & $1.64(1.19,2.25)$ & 0.002 \\
\hline \multicolumn{7}{|c|}{ Avoid Large Gatherings } \\
\hline Yes & 1.00 & & 1.00 & & 1.00 & \\
\hline No & $1.12(0.86,1.47)$ & 0.398 & $1.72(1.35,2.19)$ & $<0.001$ & $1.18(0.88,1.58)$ & 0.257 \\
\hline \multicolumn{7}{|c|}{ Advocating People About the Health Risk Related to COVID-19 } \\
\hline Yes & 1.00 & & 1.00 & & 1.00 & \\
\hline No & $0.55(0.45,0.68)$ & $<0.001$ & $0.99(0.81,1.21)$ & 0.916 & $0.66(0.51,0.84)$ & 0.001 \\
\hline \multicolumn{7}{|c|}{ Health Condition experienced in previous before the survey } \\
\hline \multicolumn{7}{|c|}{ Fever } \\
\hline No & 1.00 & & 1.00 & & 1.00 & \\
\hline Yes & $0.96(0.78,1.17)$ & 0.663 & $1.11(0.93,1.32)$ & 0.252 & $1.07(0.88,1.31)$ & 0.509 \\
\hline \multicolumn{7}{|c|}{ Chills } \\
\hline No & 1.00 & & 1.00 & & 1.00 & \\
\hline Yes & $1.99(1.62,2.44)$ & $<0.001$ & $2.07(1.72,2.49)$ & $<0.001$ & $2.01(1.65,2.46)$ & $<0.001$ \\
\hline
\end{tabular}


27 | Prevalence and Factors associated with Mental health impact of COVID-19 Pandemic in Bangladesh: A survey based cross sectional study

\begin{tabular}{|c|c|c|c|c|c|c|}
\hline \multicolumn{7}{|c|}{ Headache } \\
\hline No & 1.00 & & 1.00 & & 1.00 & \\
\hline Yes & $1.26(1.08,1.48)$ & 0.004 & $1.63(1.42,1.86)$ & $<0.001$ & $1.50(1.29,1.75)$ & $<0.001$ \\
\hline \multicolumn{7}{|c|}{ Cough } \\
\hline No & 1.00 & & 1.00 & & 1.00 & \\
\hline Yes & $1.27(1.08,1.50)$ & 0.004 & $1.79(1.56,2.07)$ & $<0.001$ & $1.32(1.12,1.55)$ & 0.001 \\
\hline \multicolumn{7}{|c|}{ Breathing Difficulty } \\
\hline No & 1.00 & & 1.00 & & 1.00 & \\
\hline Yes & $2.14(1.74,2.62)$ & $<0.001$ & $1.73(1.44,2.08)$ & $<0.001$ & $2.18(1.79,2.66)$ & $<0.001$ \\
\hline \multicolumn{7}{|c|}{ Dizziness } \\
\hline No & 1.00 & & 1.00 & & 1.00 & \\
\hline Yes & $1.45(1.20,1.76)$ & $<0.001$ & $1.91(1.63,2.25)$ & $<0.001$ & $1.50(1.25,1.80)$ & $<0.001$ \\
\hline \multicolumn{7}{|c|}{ Sore Throat } \\
\hline No & 1.00 & & 1.00 & & 1.00 & \\
\hline Yes & $1.33(1.11,1.60)$ & 0.002 & $1.38(1.18,1.61)$ & $<0.001$ & $1.39(1.16,1.66)$ & $<0.001$ \\
\hline
\end{tabular}

Adjusted odd ratios (aOR); 95\% confidence intervals (CI) 
medRxiv preprint doi: https://doi.org/10.1101/2021.01.05.21249216; this version posted January 9, 2021. The copyright holder for this preprint (which was not certified by peer review) is the author/funder, who has granted medRxiv a license to display the preprint in All rights reserved Norpetuity.

perpetuity.
reuse allowed without permission.

28 | Prevalence and Factors associated with Mental health impact of COVID-19 Pandemic in Bangladesh: A survey based cross sectional study

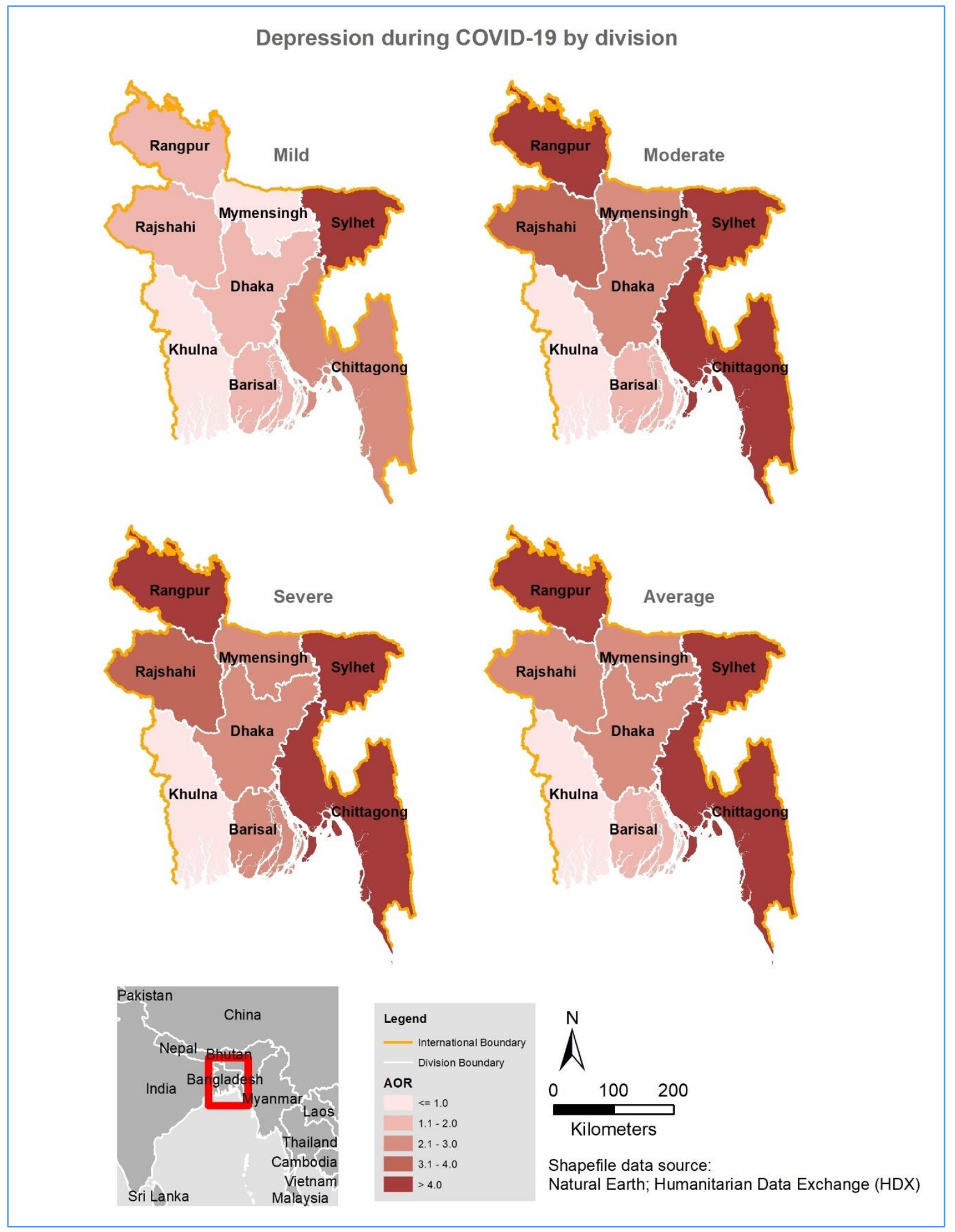

Figure 2 Spatial distribution of depression during COVID-19 in Bangladesh by division 
medRxiv preprint doi: https://doi.org/10.1101/2021.01.05.21249216; this version posted January 9, 2021. The copyright holder for this preprint (which was not certified by peer review) is the author/funder, who has granted medRxiv a license to display the preprint in All rights reserveduity.

perpetuity.
reuse allowed without permission.

29 | Prevalence and Factors associated with Mental health impact of COVID-19 Pandemic in Bangladesh: A survey based cross sectional study

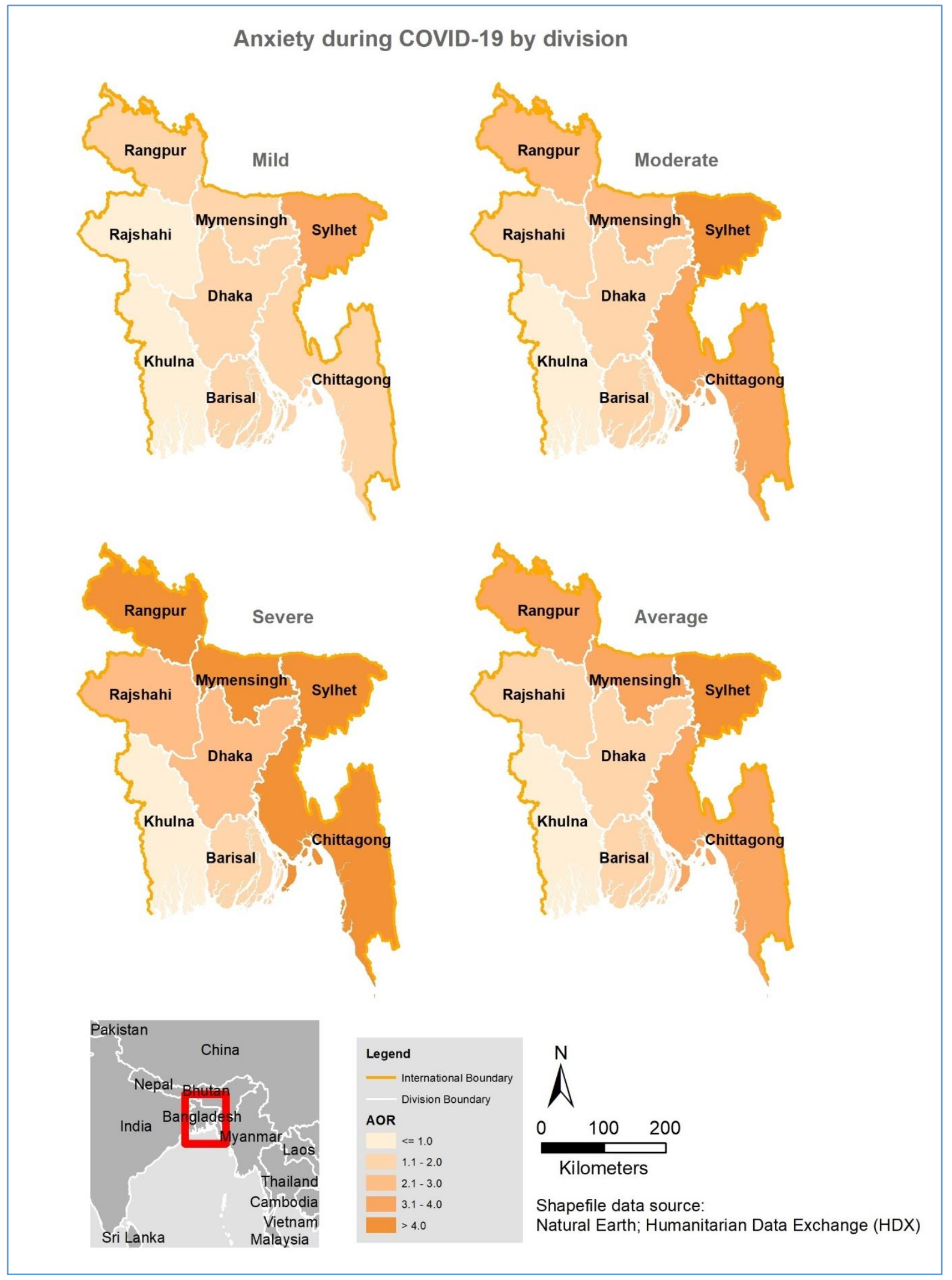

Figure 3 Spatial distribution of anxiety during COVID-19 in Bangladesh by division 
medRxiv preprint doi: https://doi.org/10.1101/2021.01.05.21249216; this version posted January 9, 2021. The copyright holder for this preprint (which was not certified by peer review) is the author/funder, who has granted medRxiv a license to display the preprint in

All rights reserved. No reuse allowed without permission.

30 | Prevalence and Factors associated with Mental health impact of COVID-19 Pandemic in Bangladesh: A survey based cross sectional study

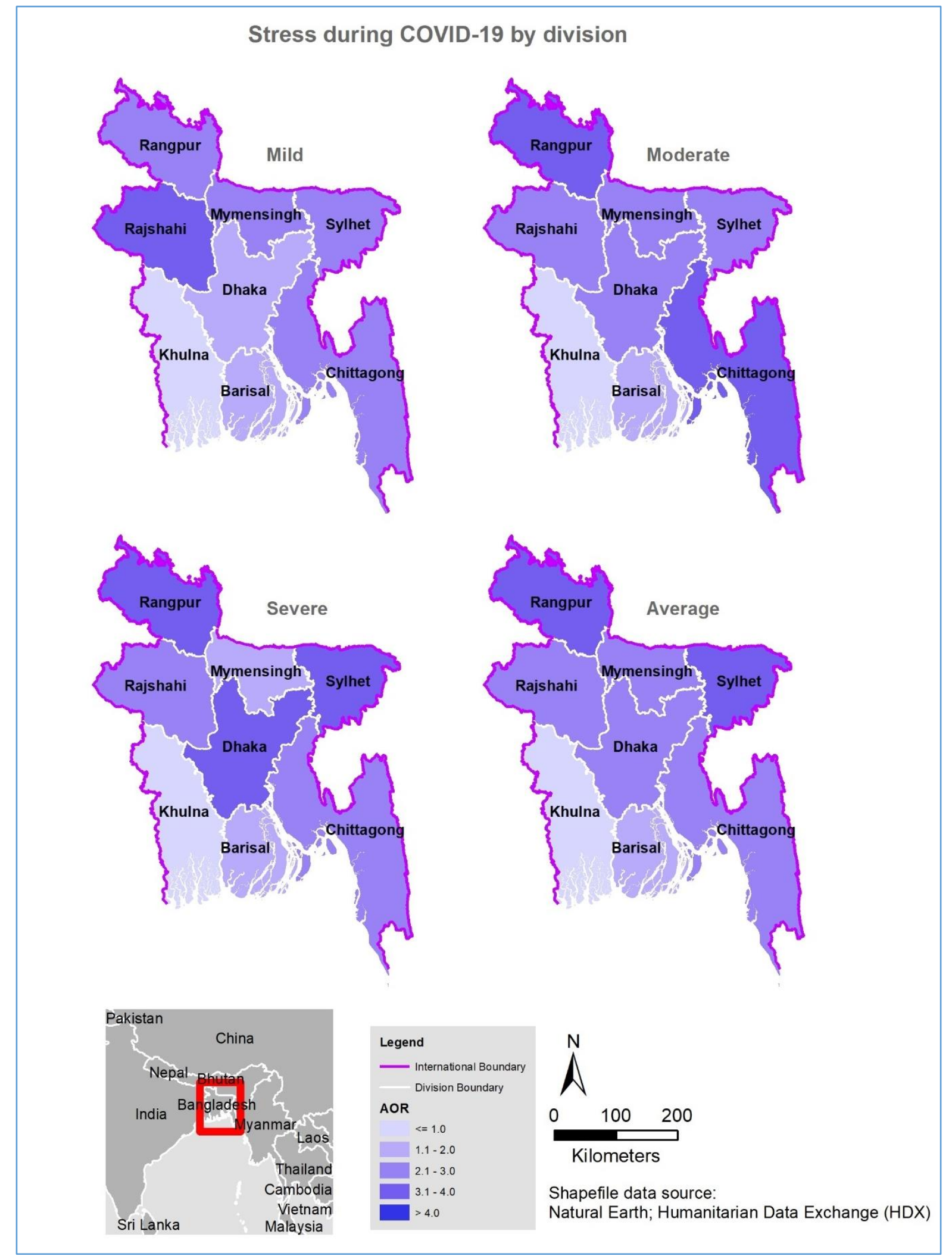

Figure 4 Spatial distribution of stress during COVID-19 in Bangladesh by division 
medRxiv preprint doi: https://doi.org/10.1101/2021.01.05.21249216; this version posted January 9, 2021. The copyright holder for this preprint (which was not certified by peer review) is the author/funder, who has granted medRxiv a license to display the preprint in All rights reserved. perpetuity. perpetuity.

31 Prevalence and Factors associated with Mental health impact of COVID-19 Pandemic in Bangladesh: A survey based cross sectional study

\section{Discussion}

This cross-sectional survey assessed the prevalence and associated factors of mental health symptoms related to the COVID-19 pandemic in Bangladesh using an online survey. The study found a high prevalence of mental health symptoms during the pandemic, particularly feeling anxious and depressed while about half of the respondents experienced stress. Respondents who reported these mental health symptoms during the pandemic were more likely to be females, married, have lower education, faced by various factors related to accommodation and living arrangements, and those who experienced COVID-19 related health symptoms. In addition, respondents who were tested for COVID-19, those who traveled via public transport, and people who practiced self-quarantine self-reported a higher prevalence of depression, anxiety, and stress in this study.

The prevalence of mental health symptoms found in this study was higher than previous studies conducted elsewhere during the COVID-19 pandemic including those from the United Kingdom [20] and Iran [21] where two in five respondents reported some form of depression. Similarly, studies in Asia have shown that people experienced substantial psychological problems during the pandemic $[22,23]$. The authors attributed factors such as the recommended self-quarantine and isolation measures, employment uncertainty, and the rapid spread of COVID-19 related misinformation [24]. A similar high prevalence of depression and anxiety was reported among those with chronic medical problems in Ethiopia during the COVID-19 pandemic [25], and in Australia, a high prevalence of psychological distress was reported during the highly infectious equine influenza in 2007 [26]. The higher prevalence of mental health symptoms found in this study compared to previous studies may be due to the difference in the study population between studies as well as the socio-cultural differences and the methods used in assessing the mental health symptoms. 
medRxiv preprint doi: https://doi.org/10.1101/2021.01.05.21249216; this version posted January 9,2021 . The copyright holder for this preprint (which was not certified by peer review) is the author/funder, who has granted medRxiv a license to display the preprint in All rights reserved. perpetuity. perpetuity.

32 | Prevalence and Factors associated with Mental health impact of COVID-19 Pandemic in Bangladesh: A survey based cross sectional study

Previous epidemiological studies found that women had a higher risk of depression [27] than men and were more vulnerable to stress and post-traumatic stress disorder [28]. These findings were corroborated in recent studies where the prevalence of anxiety, depression, and stress during the COVID-19 pandemic was significantly higher among women than men [29, 30, 31]. Compared with the previous studies the present study used a larger sample size to confirm that women in Bangladesh experienced significantly higher mental health symptoms than men and this could be due to the higher representation of women in various industries like retail, manufacturing, healthcare, and service industries, affected by the current pandemic. These findings are also in agreement with the suggestion that, with the uneven effects in the employment sector, women were more likely to experience psychological and mental health problems when faced with depression, anxiety, and stress [32].

Older people had a higher risk of COVID-19 infection and mortality [33]., however, the results of existing studies found higher levels of anxiety, depression, and stress among the younger population particularly those aged 21-40years [11, 34]. In the present study, age had a significant effect on the participants' report of mental health symptoms of depression, anxiety, and stress. This may be attributed to the fact that people in this age group are more concerned over the future consequences and economic challenges caused by the pandemic, as they are the key actors working force in society and are, therefore, mostly affected by fear of joblessness and business closures [35]. Some researchers have argued that greater anxiety among young people may be related to their greater access to information through social media, which can also cause severe stress $[22,36]$. It has also been suggested that people become stressed and feel anxious when the information from public health experts are unreliable or was delivered incorrectly and as such could create confusion regarding the practice of self-quarantine or other public health measures put in place to control the spread of a pandemic [37]. 
medRxiv preprint doi: https://doi.org/10.1101/2021.01.05.21249216; this version posted January 9, 2021. The copyright holder for this preprint (which was not certified by peer review) is the author/funder, who has granted medRxiv a license to display the preprint in All rights reserved. perpetuity. perpetuity.

33 | Prevalence and Factors associated with Mental health impact of COVID-19 Pandemic in Bangladesh: A survey based cross sectional study

This study found a significant association between level of education and the mental health symptoms during the pandemic which was consistent with a study from China that was conducted at the initial stage of the COVID-19 outbreak [38]. In that study, those with no formal education were more likely to report depression during the epidemic. Other studies have also reported significant associations between the lower level of education, and anxiety and depression levels $[\mathbf{2 0}, \mathbf{2 5}]$. In contrast to these studies, we found that during the COVID19 pandemic, respondents in Bangladesh who had a higher level of education reported higher levels of anxiety, depression, and stress [31, 39]. It was because $59.75 \%$ of respondents of our study had the university level of education in comparison to respondents of the previous studies. Even some recent studies also revealed similar findings as our study did [40]

Similar to the findings of this study, some authors in China $[38,41]$ reported higher levels of anxiety among participants who had at least one family member, relative, or friend with COVID-19. Also, those who were separated or widowed/divorced were more likely to experience depression during the pandemic than other respondents which was consistent with a previous study in the USA [42] during the pandemic. Before the pandemic, a study in Pakistan revealed that among the older population, those who lived in a nuclear family system were more likely to report depression compared to those who lived in a joint family system [43].

During the early outbreak of COVID-19 in Bangladesh, people who had potentially come into contact with the infection were asked to isolate themselves at home or in a dedicated quarantine facility [1]. The findings of negative psychological effects of these measures in this study have consisted with other studies which found that lockdown and self-quarantine during the pandemic like SARS, MARS, and COVID-19 had higher levels of post-traumatic stress symptoms, confusion, and anger [29, 36]. In our study, more than two-thirds of those who practiced self-quarantine reported mental health issues. Due to the self-quarantine 
medRxiv preprint doi: https://doi.org/10.1101/2021.01.05.21249216; this version posted January 9, 2021. The copyright holder for this preprint (which was not certified by peer review) is the author/funder, who has granted medRxiv a license to display the preprint in All rights reserved. perpetuity. perpetuity.

34 | Prevalence and Factors associated with Mental health impact of COVID-19 Pandemic in Bangladesh: A survey based cross sectional study

measures and fear related to the spread of COVID-19, other persistent mental health disorders like anxiety, emotional disruption, and exhaustion, depression, anger, irritability, insomnia, and stress can be developed among the population [44]. Moreover, the longer the quarantine or self-isolation, the more detrimental these outcomes can become [45].

This study had some limitations. First, it was limited in scope. Many of the participants (50\%) were from the capital city of Dhaka division, limiting the generalization of our findings to rural regions. Second, the study was carried out during the COVID-19 lockdown period and lacked longitudinal follow-up. The analysis of the periodic state of individuals may not reflect the psychological state, which changes with time and with the alterations in one's surrounding environment. Because of the increasingly arduous situation and the fear of the second wave, the mental health symptoms of residents could become more severe. Thus, the long-term psychological implications of this population are worth further investigation. Third, due to ethical requirements on anonymity and confidentiality, we were not allowed to collect contact details and personal information from the respondents. As a result, we could not conduct a prospective study that would provide a concrete finding to support the need for a focused public health initiative. Fourth, the study was not able to distinguish between preexisting mental health symptoms and new symptoms. Fifth, there was an oversampling of a particular network of peers (e.g., students), which may lead to selection bias. However, a large percentage of respondents who were within 40 years old consisted of students. They were exposed to higher mental health symptoms due to the temporary shutdown of educational institutions, disbandment of social gatherings, and the pressure from having to attend classes online [46]. Sixth, the self-reported levels of psychological impact, anxiety, depression, and stress may not always align with assessment by mental health professionals. Despite these limitations, this study has several strengths. Further, then providing insight on the actual existing pandemic situation, this study sheds added light on the impact of COVID- 
medRxiv preprint doi: https://doi.org/10.1101/2021.01.05.21249216; this version posted January 9,2021 . The copyright holder for this preprint (which was not certified by peer review) is the author/funder, who has granted medRxiv a license to display the preprint in All rights reserved. perpetuity.

perpetuity.

35 | Prevalence and Factors associated with Mental health impact of COVID-19 Pandemic in Bangladesh: A survey based cross sectional study

19 on the mental health conditions of the educated people in Bangladesh who are the potential future workforce as well.

\section{Conclusions}

In this survey study conducted in Bangladesh, respondents reported high rates of symptoms of depression, anxiety, and distress while non-compliance with public health measures increased the risk of mental health outcomes. Protecting the Bangladesh population is an important component of public health measures for addressing the COVID-19 epidemic. Special interventions to promote mental wellbeing in Bangladesh communities exposed to COVID-19 need to be immediately implemented, with women, married people, the less educated people, and those that were tested for COVID-19 requiring particular attention. To further close the gap in the relationship and improve the mental health wellbeing of the Bangladeshi people, alternative ways of communication such as the use of internet video calls [47] should be promoted during similar situations.

\section{References}

1. Abir T, Kalimullah NA, Osuagwu UL, et al. Factors associated with the perception of risk and knowledge of contracting the SARS-Cov-2 among adults in Bangladesh: Analysis of online surveys. Int J Environ Res Public Health. 2020;17(14):5252.

2. Bong C-L, Brasher C, Chikumba E, McDougall R, Mellin-Olsen J, Enright A. The COVID-19 pandemic: Effects on low- and middle-income countries. Anesth Analg. 2020;131(1):86-92.

3. Sabawoon W. Differences by country-level income in COVID-19 cases, deaths, casefatality rates, and rates per million population in the first five months of the pandemic. bioRxiv. Published online 2020. doi:10.1101/2020.07.13.20153064 
medRxiv preprint doi: https://doi.org/10.1101/2021.01.05.21249216; this version posted January 9, 2021. The copyright holder for this preprint (which was not certified by peer review) is the author/funder, who has granted medRxiv a license to display the preprint in All rights perpetuity.

perpetuity.
reuse allowed without permission.

36 | Prevalence and Factors associated with Mental health impact of COVID-19 Pandemic in Bangladesh: A survey based cross sectional study

4. Corman VM, Landt O, Kaiser M, et al. Detection of 2019 novel coronavirus (2019nCoV) by real-time RT-PCR. Euro Surveill. 2020;25(3). doi:10.2807/15607917.ES.2020.25.3.2000045

5. Krammer F. SARS-CoV-2 vaccines in development. Nature. 2020;586(7830):516527.

6. Diaz A, Marthaler D, Culhane M, Sreevatsan S, Alkhamis M, Torremorell M. Complete genome sequencing of influenza A viruses within swine farrow-to-wean farms reveals the emergence, persistence, and subsidence of diverse viral genotypes. $J$ Virol. 2017;91(18). doi:10.1128/JVI.00745-17

7. Alanagreh L, Alzoughool F, Atoum M. The human Coronavirus disease COVID-19: Its origin, characteristics, and insights into potential drugs and its mechanisms. Pathogens. 2020;9(5):331.

8. Wang H, Li X, Li T, et al. The genetic sequence, origin, and diagnosis of SARS-CoV2. Eur J Clin Microbiol Infect Dis. 2020;39(9):1629-1635.

9. Weekly operational update on COVID-19 - 30 November 2020. Who.int. Accessed December 27, 2020. https://www.who.int/publications/m/item/weekly-operationalupdate---30-november-2020

10. Ahorsu DK, Lin C-Y, Imani V, Saffari M, Griffiths MD, Pakpour AH. The fear of COVID-19 scale: Development and initial validation. Int J Ment Health Addict. Published online 2020:1-9.

11. Chen B, Sun J, Feng Y. How have COVID-19 isolation policies affected young people's mental health? - evidence from Chinese college students. Front Psychol. 2020;11:1529.

12. Amit S. Coronavirus and impact on the Bangladesh economy: Assessing the damage of the black swan of 2020. Asia-Pacific Journal Japan Focus. 2020;18(15-9). 
medRxiv preprint doi: https://doi.org/10.1101/2021.01.05.21249216; this version posted January 9, 2021. The copyright holder for this preprint (which was not certified by peer review) is the author/funder, who has granted medRxiv a license to display the preprint in All rights reserved. No reuse allowed without permission.

37 | Prevalence and Factors associated with Mental health impact of COVID-19 Pandemic in Bangladesh: A survey based cross sectional study

13. Vahdani B, Javadi SMH, Sabzi Khoshnami M, Arian M. Grief process and the COVID-19 pandemic: Wise intervention in vulnerable groups and survivors. Iran J Psychiatry Behav Sci. 2020;In Press(In Press). doi:10.5812/ijpbs.103855.

14. Kecojevic A, Basch CH, Sullivan M, Davi NK. The impact of the COVID-19 epidemic on mental health of undergraduate students in New Jersey, cross-sectional study. PLoS One. 2020;15(9):e0239696.

15. Esposito V, Rania E, Lico D, et al. Influence of COVID-19 pandemic on the psychological status of infertile couples. Eur J Obstet Gynecol Reprod Biol. 2020;253:148-153.

16. https://www.who.int/workforcealliance/media/news/2012/bgd_stakeholder2012/en/. https://www.who.int/.

17. Nuri NN, Sarker M, Ahmed HU, Hossain MD, Beiersmann C, Jahn A. Pathways to care of patients with mental health problems in Bangladesh. Int J Ment Health Syst. 2018;12(1). doi:10.1186/s13033-018-0218-y.

18. Lovibond PF, Lovibond SH. The structure of negative emotional states: comparison of the Depression Anxiety Stress Scales (DASS) with the Beck Depression and Anxiety Inventories. Behav Res Ther. 1995;33(3):335-343.

19. ArcUser. $\quad$ Esri.com. $\quad$ Accessed $\quad$ December $\quad 29,202$. https://www.esri.com/news/arcuser/0610/files/arcuser50/70.html

20. Fancourt D, Steptoe A, Bu F. Trajectories of anxiety and depressive symptoms during enforced isolation due to COVID-19: longitudinal analyses of 36,520 adults in England. bioRxiv. Published online 2020. doi:10.1101/2020.06.03.20120923.

21. Salari N, Hosseinian-Far A, Jalali R, et al. Prevalence of stress, anxiety, depression among the general population during the COVID-19 pandemic: a systematic review and meta-analysis. Global Health. 2020;16(1):57. 
medRxiv preprint doi: https://doi.org/10.1101/2021.01.05.21249216; this version posted January 9, 2021. The copyright holder for this preprint (which was not certified by peer review) is the author/funder, who has granted medRxiv a license to display the preprint in All rights perpetuity. reuse allowed without permission.

38 | Prevalence and Factors associated with Mental health impact of COVID-19 Pandemic in Bangladesh: A survey based cross sectional study

22. Gao J, Zheng P, Jia Y, et al. Mental health problems and social media exposure during COVID-19 outbreak. PLoS One. 2020;15(4):e0231924.

23. Xiao H, Zhang Y, Kong D, Li S, Yang N. The effects of social support on sleep quality of medical staff treating patients with Coronavirus disease 2019 (COVID-19) in January and February 2020 in China. Med Sci Monit. 2020;26:e923549.

24. Xiong J, Lipsitz O, Nasri F, et al. Impact of COVID-19 pandemic on mental health in the general population: A systematic review. J Affect Disord. 2020;277:55-64.

25. Hajure M, Tariku M, Mohammedhussein M, Dule A. Depression, anxiety and associated factors among chronic medical patients amid COVID-19 pandemic in Mettu Karl Referral Hospital, Mettu, Ethiopia, 2020. Neuropsychiatr Dis Treat. 2020;16:2511-2518.

26. Taylor MR, Agho KE, Stevens GJ, Raphael B. Factors influencing psychological distress during a disease epidemic: data from Australia's first outbreak of equine influenza. BMC Public Health. 2008;8(1):347.

27. Lim GY, Tam WW, Lu Y, Ho CS, Zhang MW, Ho RC. Prevalence of depression in the community from 30 countries between 1994 and 2014. Sci Rep. 2018;8(1). doi:10.1038/s41598-018-21243-x.

28. Sareen J, Erickson J, Medved MI, et al. Risk factors for post-injury mental health problems: Review: Post-injury mental health problems. Depress Anxiety. 2013;30(4):321-327.

29. Liu D, Ren Y, Yan F, et al. Psychological impact and predisposing factors of the Coronavirus disease 2019 (COVID-19) pandemic on general public in China. SSRN Electron J. Published online 2020. doi:10.2139/ssrn.3551415.

30. Talevi D, Socci V, Carai M, et al. Mental health outcomes of the CoViD-19 pandemic. Riv Psichiatr. 2020;55(3):137-144. 
medRxiv preprint doi: https://doi.org/10.1101/2021.01.05.21249216; this version posted January 9, 2021. The copyright holder for this preprint (which was not certified by peer review) is the author/funder, who has granted medRxiv a license to display the preprint in All rights reserved. No reuse allowed without permission.

39 | Prevalence and Factors associated with Mental health impact of COVID-19 Pandemic in Bangladesh: A survey based cross sectional study

31. Wang Y, Di Y, Ye J, Wei W. Study on the public psychological states and its related factors during the outbreak of coronavirus disease 2019 (COVID-19) in some regions of China. Psychol Health Med. Published online 2020:1-10.

32. Eid RS, Gobinath AR, Galea LAM. Sex differences in depression: Insights from clinical and preclinical studies. Prog Neurobiol. 2019;176:86-102.

33. Mahase E. Covid-19: death rate is $0.66 \%$ and increases with age, study estimates. BMJ: British Medical Journal (Online. 2020;369.

34. Hyland P, Shevlin M, McBride O, et al. Anxiety and depression in the Republic of Ireland during the COVID-19 pandemic. Acta Psychiatr Scand. 2020;142(3):249-256.

35. Ahmed MZ, Ahmed O, Aibao Z, Hanbin S, Siyu L, Ahmad A. Epidemic of COVID19 in China and associated Psychological Problems. Asian $J$ Psychiatr. 2020;51(102092):102092.

36. Brooks SK, Webster RK, Smith LE, et al. The psychological impact of quarantine and how to reduce it: rapid review of the evidence. Lancet. 2020;395(10227):912-920.

37. Cava MA, Fay KE, Beanlands HJ, McCay EA, Wignall R. The experience of quarantine for individuals affected by SARS in Toronto. Public Health Nurs. 2005;22(5):398-406.

38. Wang C, Pan R, Wan X, et al. Immediate psychological responses and associated factors during the initial stage of the 2019 Coronavirus disease (COVID-19) epidemic among the general population in China. Int $J$ Environ Res Public Health. 2020;17(5):1729.

39. Zhang Y, Ma ZF. Impact of the COVID-19 pandemic on mental health and quality of life among local residents in Liaoning Province, China: A cross-sectional study. Int J Environ Res Public Health. 2020;17(7):2381. 
medRxiv preprint doi: https://doi.org/10.1101/2021.01.05.21249216; this version posted January 9, 2021. The copyright holder for this preprint (which was not certified by peer review) is the author/funder, who has granted medRxiv a license to display the preprint in All rights rerpetuity.

perpetuity.
reuse allowed without permission.

40 | Prevalence and Factors associated with Mental health impact of COVID-19 Pandemic in Bangladesh: A survey based cross sectional study

40. Groarke JM, Berry E, Graham-Wisener L, McKenna-Plumley PE, McGlinchey E, Armour C. Loneliness in the UK during the COVID-19 pandemic: Cross-sectional results from the COVID-19 Psychological Wellbeing Study. PLoS One. 2020;15(9):e0239698.

41. Fegert JM, Vitiello B, Plener PL, Clemens V. Challenges and burden of the Coronavirus 2019 (COVID-19) pandemic for child and adolescent mental health: a narrative review to highlight clinical and research needs in the acute phase and the long return to normality. Child Adolesc Psychiatry Ment Health. 2020;14(1):20.

42. Ettman CK, Abdalla SM, Cohen GH, Sampson L, Vivier PM, Galea S. Prevalence of depression symptoms in US adults before and during the COVID-19 pandemic. JAMA Netw Open. 2020;3(9):e2019686.

43. Taqui AM, Itrat A, Qidwai W, Qadri Z. Depression in the elderly: does family system play a role? A cross-sectional study. BMC Psychiatry. 2007;7:57.

44. Serafini G, Parmigiani B, Amerio A, Aguglia A, Sher L, Amore M. The psychological impact of COVID-19 on the mental health in the general population. QJM. 2020;113(8):531-537.

45. Stickley A, Koyanagi A. Loneliness, common mental disorders and suicidal behavior: Findings from a general population survey. J Affect Disord. 2016;197:81-87.

46. Samadarshi SCA, Sharma S, Bhatta J. An online survey of factors associated with self-perceived stress during the initial stage of the COVID-19 outbreak in Nepal. The Ethiopian Journal of Health Development (EJHD. 2020;34(2).

47. Schäfer SK, Sopp MR, Schanz CG, Staginnus M, Göritz AS, Michael T. Impact of COVID-19 on public mental health and the buffering effect of a sense of coherence. Psychother Psychosom. 2020;89(6):386-392. 
medRxiv preprint doi: https://doi.org/10.1101/2021.01.05.21249216; this version posted January 9, 2021. The copyright holder for this preprint (which was not certified by peer review) is the author/funder, who has granted medRxiv a license to display the preprint in perpetuity.

All rights reserved. No reuse allowed without permission.

41 | Prevalence and Factors associated with Mental health impact of COVID-19 Pandemic in Bangladesh: A survey based cross sectional study

Supplementary Table 1: Sample of survey items and their test of reliability

\begin{tabular}{|c|c|}
\hline $\begin{array}{ccc}\text { Did not apply to me } & \text { Applied to me to some degree or } & \text { Applied to me to a considerable degree or } \\
\text { at all (0) } & \text { some of the time (1) } & \text { most of the time (2) }\end{array}$ & $\begin{array}{l}\text { Applied to me very much or most } \\
\text { of the time (3) }\end{array}$ \\
\hline Depression subscale & Cronbach's Alpha \\
\hline 3. I couldn't seem to experience any positive feeling at all & 0.7618 \\
\hline 5. I found it difficult to work up the initiative to do things & 0.7661 \\
\hline 10. I felt that I had nothing to look forward to & 0.7594 \\
\hline 13. I felt downhearted and blue & 0.7690 \\
\hline 16. I was unable to become enthusiastic about anything & 0.7650 \\
\hline 17. I felt I wasn't worth much as a person & 0.7330 \\
\hline 21. I felt that life was meaningless & 0.7633 \\
\hline Anxiety subscale & Cronbach's Alpha \\
\hline 2. I was aware of dryness of my mouth & 0.6644 \\
\hline $\begin{array}{l}\text { 4. I experienced breathing difficulty (e.g. excessively rapid breathing, breathlessness in the absence of physical } \\
\text { exertion) }\end{array}$ & 0.6768 \\
\hline 7. I experienced trembling (e.g. in the hands) & 0.7720 \\
\hline 9. I was worried about situations in which I might panic and make a fool of myself & 0.6668 \\
\hline 15. I felt I was close to panic & 0.6648 \\
\hline $\begin{array}{l}\text { 19. I was aware of the action of my heart in the absence of physical exertion (e.g. sense of heart rate increase, } \\
\text { heart missing a beat) }\end{array}$ & 0.6513 \\
\hline 20. I felt scared without any good reason & 0.6511 \\
\hline Stress subscale & Cronbach's Alpha \\
\hline 1. I found it hard to wind down & 0.8100 \\
\hline 6. I tended to over-react to situations & 0.7894 \\
\hline 8. I felt that I was using a lot of nervous energy & 0.7776 \\
\hline 11. I found myself getting agitated & 0.7877 \\
\hline 12. I found it difficult to relax & 0.7775 \\
\hline 14. I was intolerant of anything that kept me from getting on with what I was doing & 0.7822 \\
\hline 18. I felt that I was rather touchy & 0.7823 \\
\hline
\end{tabular}


medRxiv preprint doi: https://doi.org/10.1101/2021.01.05.21249216; this version posted January 9, 2021. The copyright holder for this preprint (which was not certified by peer review) is the author/funder, who has granted medRxiv a license to display the preprint in

All rights reserved. No reuse allowed without permission.

$42 \mid$ Prevalence and Factors associated with Mental health impact of COVID-19 Pandemic in Bangladesh: A survey based cross sectional study

\section{Supplementary Table 2}

A survey questionnaire on Mental health and psychological impact of the coronavirus disease 2019 (COVID-19) outbreak: A cross-sectional study on Bangladeshi People

\section{Socio-Demographic Profile of the Respondent:}

\begin{tabular}{|c|c|c|}
\hline Name & & \\
\hline \multirow{3}{*}{ What is your gender } & Male & 1 \\
\hline & Female & 2 \\
\hline & Other & 88 \\
\hline \multirow{8}{*}{ Level of study (year) } & Under SSC & 1 \\
\hline & SSC or Equivalent & 2 \\
\hline & HSC or Equivalent & 3 \\
\hline & Graduate & 4 \\
\hline & Post Graduate & 5 \\
\hline & Doctorate & 6 \\
\hline & Post Doctorate & 7 \\
\hline & Other & 88 \\
\hline \multirow{8}{*}{ Your Mother's Schooling } & Under SSC & 1 \\
\hline & SSC or Equivalent & 2 \\
\hline & HSC or Equivalent & 3 \\
\hline & Graduate & 4 \\
\hline & Post Graduate & 5 \\
\hline & Doctorate & 6 \\
\hline & Post Doctorate & 7 \\
\hline & Other & 88 \\
\hline \multirow{8}{*}{ Your Father's Schooling } & Under SSC & 1 \\
\hline & SSC or Equivalent & 2 \\
\hline & HSC or Equivalent & 3 \\
\hline & Graduate & 4 \\
\hline & Post Graduate & 5 \\
\hline & Doctorate & 6 \\
\hline & Post Doctorate & 7 \\
\hline & Other & 88 \\
\hline What is your age? & & \#\# \\
\hline \multirow{3}{*}{ Marital Status } & Single & 1 \\
\hline & Married & 2 \\
\hline & Divorced & 3 \\
\hline
\end{tabular}


medRxiv preprint doi: https://doi.org/10.1101/2021.01.05.21249216; this version posted January 9, 2021. The copyright holder for this preprint (which was not certified by peer review) is the author/funder, who has granted medRxiv a license to display the preprint in

All rights reserved. No reuse allowed without permission.

43 | Prevalence and Factors associated with Mental health impact of COVID-19 Pandemic in Bangladesh: A survey based cross sectional study

\begin{tabular}{|c|c|c|}
\hline & Widowed & 4 \\
\hline \multirow{4}{*}{ What is your professional status? } & Student & 1 \\
\hline & Working (Full Time) & 2 \\
\hline & Working (Part-Time & 3 \\
\hline & None & 4 \\
\hline \multirow{4}{*}{ Living Arrangement } & Living Alone & 1 \\
\hline & Living with Family & 2 \\
\hline & Living with flatmates & 3 \\
\hline & Others & 88 \\
\hline Which district are you currently living in & & \#\# \\
\hline Which district you originally belong to & & \#\# \\
\hline \multirow{3}{*}{ Have you been tested for COVID-19? } & Yes, I tested positive & 1 \\
\hline & Yes, I tested negative & 2 \\
\hline & No & 3 \\
\hline \multirow{2}{*}{$\begin{array}{l}\text { Have you enforced protective measures inside your home to } \\
\text { protect yourself and your family from COVID 19? }\end{array}$} & Yes & 1 \\
\hline & No & 2 \\
\hline \multirow{2}{*}{ Are you currently in Self-Quarantine since past seven days? } & Yes & 1 \\
\hline & No & 2 \\
\hline \multirow{7}{*}{ What sort of protective measures have you taken? } & Avoid public transportation & 1 \\
\hline & Avoid shaking hands & 2 \\
\hline & Wearing face mask & 3 \\
\hline & Avoid large gatherings & 4 \\
\hline & $\begin{array}{l}\text { Advocating people about the health } \\
\text { risk related to COVID-19 }\end{array}$ & 5 \\
\hline & All of the above & 6 \\
\hline & None of the above & 7 \\
\hline \multirow{4}{*}{ What is your household size? } & One person & 1 \\
\hline & Two people & 2 \\
\hline & Three to five people & 3 \\
\hline & Six people or more & 4 \\
\hline
\end{tabular}

Physical Health Status (Please respond on your physical health since the past two weeks)

\begin{tabular}{|l|l|l|}
\hline & $\begin{array}{c}\text { Yes } \\
\text { (1) }\end{array}$ & No (2) \\
\hline Persistent fever $>\mathbf{9 8}{ }^{\circ}$ ' $\mathbf{F}^{\prime}$ ' for at least one day & & \\
\hline Chills & & \\
\hline Headache & & \\
\hline Cough & & \\
\hline
\end{tabular}


medRxiv preprint doi: https://doi.org/10.1101/2021.01.05.21249216; this version posted January 9, 2021. The copyright holder for this preprint (which was not certified by peer review) is the author/funder, who has granted medRxiv a license to display the preprint in

perpetuity.
reuse allowed without permission.

44 | Prevalence and Factors associated with Mental health impact of COVID-19 Pandemic in Bangladesh: A survey based cross sectional study

\begin{tabular}{|l|l|l|}
\hline Breathing Difficulty & & \\
\hline Dizziness & & \\
\hline Sore Throat & & \\
\hline Persistent fever and cough or difficulty breathing & & \\
\hline
\end{tabular}

\section{Mental Health Impact of COVID 19:}

Please read each statement and circle a number 1, 2, 3 or 4 which shows how much the statement has applied in the past week to you. There are no correct answers or incorrect answers.

\begin{tabular}{|c|c|c|c|c|}
\hline & $\begin{array}{l}\text { Did not } \\
\text { apply } \\
\text { to me } \\
\text { at all } \\
\text { (1) }\end{array}$ & $\begin{array}{l}\text { Applied to } \\
\text { me to some } \\
\text { degree or } \\
\text { some of the } \\
\text { time (2) }\end{array}$ & $\begin{array}{l}\text { Applied to me } \\
\text { to a } \\
\text { considerable } \\
\text { degree or most } \\
\text { of the time (3) }\end{array}$ & $\begin{array}{l}\text { Applied to } \\
\text { me very } \\
\text { much or } \\
\text { most of the } \\
\text { time (4) }\end{array}$ \\
\hline I found it hard to wind down & & & & \\
\hline I was aware of dryness of my mouth & & & & \\
\hline $\begin{array}{l}\text { I couldn't seem to experience any positive feeling at } \\
\text { all }\end{array}$ & & & & \\
\hline $\begin{array}{l}\text { I experienced breathing difficulty (e.g. excessively } \\
\text { rapid breathing, breathlessness in the absence of } \\
\text { physical exertion) }\end{array}$ & & & & \\
\hline $\begin{array}{l}\text { I found it difficult to work up the initiative to do } \\
\text { things }\end{array}$ & & & & \\
\hline I tended to over-react to situations & & & & \\
\hline I experienced trembling (e.g. in the hands) & & & & \\
\hline I felt that I was using a lot of nervous energy & & & & \\
\hline $\begin{array}{l}\text { I was worried about situations in which I might panic } \\
\text { and make a fool of myself }\end{array}$ & & & & \\
\hline I felt that I had nothing to look forward to & & & & \\
\hline I found myself getting agitated & & & & \\
\hline I found it difficult to relax & & & & \\
\hline I felt down-hearted and blue & & & & \\
\hline $\begin{array}{l}\text { I was intolerant of anything that kept me from getting } \\
\text { on with what I was doing }\end{array}$ & & & & \\
\hline I felt I was close to panic & & & & \\
\hline I was unable to become enthusiastic about anything & & & & \\
\hline I felt I wasn't worth much as a person & & & & \\
\hline
\end{tabular}


medRxiv preprint doi: https://doi.org/10.1101/2021.01.05.21249216; this version posted January 9, 2021. The copyright holder for this preprint (which was not certified by peer review) is the author/funder, who has granted medRxiv a license to display the preprint in

perpetuity.
No reuse allowed without permission.

45 | Prevalence and Factors associated with Mental health impact of COVID-19 Pandemic in Bangladesh: A survey based cross sectional study

\begin{tabular}{|l|l|l|l|l|}
\hline I felt that I was rather touchy & & & \\
\hline $\begin{array}{l}\text { I was aware of the action of my heart in the absence of } \\
\text { physical exertion (e.g. sense of heart rate increase, } \\
\text { heart missing a beat) }\end{array}$ & & & & \\
\hline I felt scared without any good reason & & & & \\
\hline I felt that life was meaningless & & & & \\
\hline
\end{tabular}

Thank you for your participation

1. Akram A, Yeasmin M, Khan TEU, Khan MAAZ, Monir MBB, Tarana MN et al. Demographic Characteristics of 1082 Positive Cases of COVID-19 Patients: Experience at National Referral Laboratory of Bangladesh. Bangladesh Journal of Infectious Diseases. 2020:S22-S6. 